\title{
Management Implications for the Most Attractive Scenic Sites along the Andalusia Coast (SW Spain)
}

\author{
Alexis Mooser ${ }^{1}$, Giorgio Anfuso ${ }^{1, *(\mathbb{D})}$, Carlos Mestanza ${ }^{2}$ (D) and Allan Thomas Williams ${ }^{3,4}$ \\ 1 Departamento de Ciencias de la Tierra, Facultad de Ciencias del Mar y Ambientales, Universidad de Cádiz, \\ Polígono Río San Pedro s/n, 11510 Puerto Real, Cádiz, España; alex.moosr@gmail.com \\ 2 Facultad de Ciencias de la Vida, Universidad Estatal Amazónica, Sucumbíos EC210150, Ecuador; \\ cmestanza@ug.uchile.cl \\ 3 Faculty of Architecture, Computing and Engineering, University of Wales: Trinity Saint David (Swansea), \\ Mount Pleasant, Swansea SA1 6ED, Wales, UK; allanwilliams512@outlook.com \\ 4 CICA NOVA, Nova Universidade de Lisboa, 1099-085 Lisbon, Portugal \\ * Correspondence: giorgio.anfuso@uca.es
}

Received: 28 February 2018; Accepted: 20 April 2018; Published: 25 April 2018

check for updates

\begin{abstract}
A coastal scenery assessment was carried out at 50 sites along the $910 \mathrm{~km}$ long Andalusia coast (SW Spain) using a checklist of 26 natural and human parameters, parameter weighting matrices, and fuzzy logic. A scenic classification was utilised that can rate sites as Class I (natural areas of great scenic beauty) to Class V (urbanised areas of poor scenic interest), but, for this study, only natural sites of great scenic value were investigated; 41 sites were included in Class I, 9 in Class II and, apart from four, all of the sites were under some feature of protection-managed by the Andalusia Environmental Agency (RENPA, in Spanish). Sites belong to the Natural Park Cabo de Gata-Nijar (24\% of sites), the Natural Park of Gibraltar Strait (18\%), the Natural Place Acantilado de Maro-Cerro Gordo (12\%), and the Natural and National parks of Doñana ( $8 \%$ ). Results obtained by means of scenic evaluation constitute a sound scientific basis for any envisaged management plan for investigated coastal areas preservation/conservation and responsible future developments, especially for natural protected areas, which represent the most attractive coastal tourist destinations. With respect to natural parameters, excellent scenic values appeared to be linked to the geological setting and the presence of mountainous landscapes related to the Betic Chain. Human parameters usually show good scores because null or extremely reduced human impacts are recorded, but, at places, conflicts arose between conservation and recreational activities because visitors are often interested in beach activities more so than ecotourism. Low scores of human parameters were often related to litter presence or the unsuitable emplacement of utilities, such as informative panels, litter bins, etc.
\end{abstract}

Keywords: scenery; coastal; fuzzy logic; beach; protected area; tourism; sustainable development

\section{Introduction}

Since the term tourism first appeared in the Oxford English Dictionary in 1811, the literature on tourism has become vast and many theories and models have been initiated, an early one being 'Irridex' [1]. Tourist destination resorts are essentially products that have normally been developed or been modified to meet the specific market needs of holidaymakers and have a classic 'Tourist Area Life Cycle' (TALC) [2], in which this classic model's capacity elements cover six evolutionary stages. This hypothetical model is still in use for resort areas [3,4]. Continuous adjustments have been made in order to ensure survival in a competitive market, but some authors have argued that it has outlived its usefulness [5]. Tourism destinations arise only if they contain a certain character that plays a vital role in placing it above similar areas. Examples of environments affecting what are termed, 'Whole 
Tourist Systems' include those having spectacular scenery, flora and fauna [5], and it is this aspect that this paper is concerned with. Tourism innovations take place at the destination, i.e., 'where the most noticeable and dramatic consequences of the system occur' [6] and it is at this location where scenery-the gist of this paper-can take pride of place.'

Travel and tourism is one of the largest growth industries in the world [7,8], and, understanding its principles is complex [9]. By 2030, international tourist arrivals worldwide are expected to reach 1.8 billon visitors [8]. Tourism average contribution to GDP is c. $10 \%$ and reaches $25 \%$ for small islands and developing countries [10]. In 2016, tourism was responsible for employment of 1 out of 10 worldwide jobs and international tourism receipts grew by $2.6 \%$ with total earnings in the destinations estimated at US\$1220 billion worldwide [8].

The United States, Spain, and Thailand top the rankings in term of tourism receipts and France, United States, and Spain top the ranking order in terms of number of international visitors [8].

Many Caribbean and Mediterranean countries have developed proactive growth policies along the coastal area [11], with Spain, France, Italy, and Greece accounting for 'the most significant flow of tourists ... a sun, sea and sand (3S) market' [12] (p. 58). In 2016, Spain received 75.6 million international arrivals, i.e., a $10.3 \%$ increase with respect to 2015 , and occupied the 3 th place in the 2016 world rank for number of arrivals. Within the Spanish market, international tourists preferred Catalonia, Balearic and Canary Islands, Andalusia, and Valencia [13], meanwhile national tourists preferred Andalusia and Catalonia [14,15].

Travel for holidays, recreation, and other forms of leisure accounted for just over half of all international tourist arrivals in 2016 ( $53 \%$ or 657 million). Seventy five percent of international tourists visiting Spain are essentially interested in beach related tourist activities [16] a trait also observed at international level: beaches are a major player in tourist market $[17,18]$. Despite the importance of the beach market, beach recreation has recorded small attention in the economic literature [19]; but this has increased markedly in the 21st century and numerous questionnaires concerning beachgoers preferences have been carried out finding that five parameters are of the greatest importance to coastal visitors [20-22]: safety, facilities, water quality, no litter, and scenery, and the latter is the focus of this investigation. It is interesting that in their discussion of sun and sand tourism [23] did not mention scenery as a big tourism indicator.

It is self-evident that, 'Scenery has become a resource' [24] and is an 'economic resource and not a dispensable luxury' [25]. In past decades, tourist developments in coastal areas were essentially based on the $3 S$ market model and were almost exclusively based on financial criteria. It is noteworthy that some authors [26] argued that the 'new tourist' was fundamentally different in that he/she was more experienced, ecologically aware, spontaneous, and unpredictable, with a higher degree of flexibility and independence. Sound valuation is necessary, as it provides a means by which scenery/amenities can be compared against other resource considerations and the technique outlined in the paper exemplifies this point.

Scenic evaluation represents an extremely relevant tool for coastal preservation/conservation and development, as this provides a sound scientific basis for any envisaged management plan. In order to overcome subjectivity and quantify uncertainties, coastal scenery assessment at 50 sites along the Andalusia coast (SW Spain, Figure 1 and Table 1) was carried out according to a methodology based on fuzzy logic analysis and parameter weighting matrices [20], which enables a scenic division into five classes (excellent-poor). To date, $>4000$ scenic assessments have been carried out in Spain, Croatia, Portugal, Morocco, New Zealand, Australia, Fiji, the USA, Japan, China, Pakistan, Brazil, Colombia, Cuba, etc., and these breakpoint values have been found to be constant in all investigated countries, e.g., [27-32]. It is an extremely robust, accurate indicator of scenic quality [33].

A basic difficulty in assessing scenic-relating to, 'scenery, having beautiful or remarkable scenery' [34] quality is that of definition, as it is an abstract concept that is greatly confused by semantic difficulties, misunderstandings, and controversies [35]. Landscape, i.e., scenic value, has been assessed by many different authors using numerous techniques, such as landscape assessment numbers, scenic 
uniqueness, best/worst scores from grid squares, public attitudes and perception, among others [36-40]. In 2014 a first rate review of landscape methodologies was carried out [41]. Photographs that are relating to landscape perception have also been used with varying degree of success $[42,43]$.

The continuous and unsustainable development of coastal areas negatively impacts on the environment and society, deeply affecting economic profit and the basis of tourism in coastal areas, namely landscape beauty, biodiversity, and sea and land ecosystem services [44,45]. It is of the utmost importance to focus coastal managers' efforts on appropriate planning of tourism growth in accordance with the characteristics of local systems [46]. For example, the 2020 Spanish Master Plan for tourism development [47] accentuates eco-tourism related activities, which are based on natural, historic, and cultural heritage aspects of the coastal environment. Managers need to attempt an evaluation of scenic resources in an objective and quantitative manner [48].

Information that is obtained in this paper constitutes a basic requirement to improve knowledge on the scenic value of the most attractive areas along the Andalusia coast, most belonging to the Andalusia Network of Protected Areas (RENPA in Spanish), bearing in mind that protected areas are one of the most attractive coastal tourist destinations [49,50]. Information can be used to limit and prevent environmental degradation essentially linked to coastal urbanization [45,51], but also to suggest measures to improve the scenic value and the sustainable usage of investigated sites.

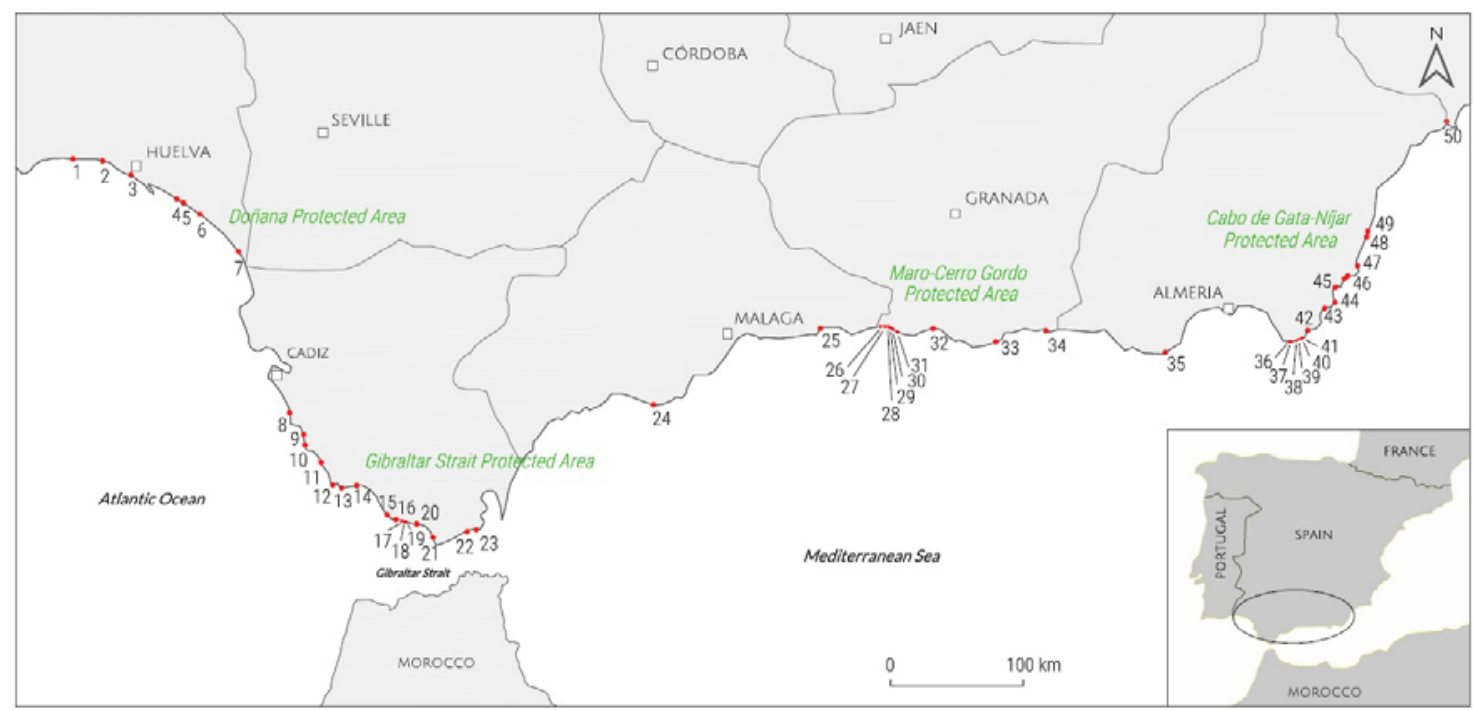

Figure 1. Location map of the investigated coastal sites.

\section{Study Area}

Andalusia's coastline extends along the Atlantic Ocean and the Mediterranean Sea (Figure 1). The Atlantic sector, some $313 \mathrm{~km}$ in length, includes Huelva and Cadiz provinces and consists of fine and medium gold coloured sands that give rise to smooth beaches and nearshore areas that are exposed to wind and waves approaching from the northwest to the south [52]. The northern sector, i.e., from Huelva to Cape Trafalgar, has a meso-tidal environment and essentially consists of a low sandy coast with long, wide beaches and coastal spits. The southern sector, i.e., from Cape Trafalgar to Tarifa, is micro-tidal and is composed of cliffs (e.g., at Barbate and Punta Camarinal) and contains sand sectors that show huge dune systems (i.e., at Bolonia and Valdevaqueros).

The Andalusia Mediterranean coast, c. $597 \mathrm{~km}$ in length, administratively includes the provinces of Cadiz, Malaga, Granada, and Almeria (Figure 1). It is micro-tidal and exposed to winds and waves approaching from SE, and, secondarily, SW [51].

Coastal physiography is dominated by the Betic Chain, a well-developed mountainous ridge that reaches high elevations that are close to the coast and includes Sierra Bartolome and Sierra de la Plata 
in Gibraltar Strait Area, Sierra Tejeda, Almijara and Alhamada at Malaga and Granada provinces, and Sierra Cabrera in Almeria ([53], accessed January 2018). Along the Mediterranean area, several coastal plains are observed, especially at the mouth of short rivers and streams (ramblas) that drain the Chain. Beaches usually consist of fine and medium dark coloured sand and/or pebbles at ramblas mouths. At places, rocky sectors and headlands give rise to pocket beaches (calas) of different sizes.

The Atlantic side of Andalusia (i.e., Huelva and Cadiz provinces) has a Mediterranean climate with an Oceanic influence, rainfall is limited (c. $600 \mathrm{~mm} /$ year), and is concentrated in autumn and winter. Average temperature in July and August is $25^{\circ} \mathrm{C}$ and the annual one is $10^{\circ} \mathrm{C}$ [54].

The Mediterranean coast broadly includes two climatic zones: (i) the provinces of Cadiz, Malaga, and Granada; and (ii) the province of Almeria. The former zone has a Mediterranean climate with sub-tropical characteristics; coastal orientation and the Betic Chain favouring average annual temperature of c. $13{ }^{\circ} \mathrm{C}$, and, in July and August the average is $19{ }^{\circ} \mathrm{C}$. Rainfall ranges from 400 to $900 \mathrm{~mm}$ with the most abundant values observed at Gibraltar Strait. The latter zone presents a Mediterranean climate with sub-desert characteristics, i.e., rainfall is extremely limited (c. $200 \mathrm{~mm}$ /year), average annual temperature is $21^{\circ} \mathrm{C}$ and July-August temperature is $26^{\circ} \mathrm{C}$ [54].

According to the Köppen classification, the coastal areas of Huelva and Cadiz provinces are categorised as Csa (Mediterranean climate), Cadiz, Malaga and Granada as Cfa (Humid subtropical climate), and Almeria as BSk (Cold semi-arid climate). In Andalusia, weather conditions make the coastal environment very attractive to national and international tourism during several months per year.

Andalusia has a total amount of 243 protected areas that show a great biodiversity [55]. Fifty protected areas are observed along the coast (i.e., c. 35\% of its coastal length is under protection) and is managed by the Andalusia Network of Protected Areas (RENPA) under different features of protection ([56], accessed February 2018), including local and national (e.g., Natural Places, National and Natural Parks, etc.) and international features (e.g., Nature 2000 Network, UNESCO Biosphere Reserve, Geoparks, etc.). The best known coastal protected areas (Figure 1) are the National Parks of Estrecho de Gibraltar ("Gibraltar Strait", in Cadiz province) and the Cabo de Gata-Nijar (Almería). Maro-Cerro Gordo is a Natural Place in Malaga province and Doñana protected area, in Huelva, made up of different zones having different forms of protection: National Park, Natural Park, UNESCO World Heritage Site, etc. ([57], accessed February 2018).

Historical heritage is very important along the Andalusia coast. Several Vigia towers, i.e., towers built in the XVI Century and is used for coastal surveillance to prevent Berber pirates' attacks, can be observed along the Mediterranean coast, but also at Huelva and Cadiz provinces. Other historical features are the ranches, which are observed at Doñana, lighthouses (e.g., Trafalgar, etc.) and castles (e.g., San Pedro, in Almeria).

Table 1. Location and main characteristics of investigated sites: name, province (P), protection feature, access difficulty (A.D.), “D” value and class.

\begin{tabular}{|c|c|c|c|c|c|}
\hline MAP NUMBER \& SITE & $\mathbf{P}$ & PROTECTION FEATURE & A.D.* & CLASS & $\mathbf{D}$ \\
\hline 1. La Casita Azul & \multirow{7}{*}{ Huelva } & None & 1 & II & 0.77 \\
\hline 2. Los Enebrales & & Natural Place Los Enebrales & 5 & $\mathrm{I}$ & 0.86 \\
\hline 3. Flecha del Rompido & & Natural Place Flecha del Rompido, SCI, SPA & 2 & I & 1.13 \\
\hline 4. Torre del Loro & & Natural Park Doñana, BR, SAC, SPA, NM & 3 & I & 1.07 \\
\hline 5. Cuesta Maneli & & Natural Park Doñana, BR, SAC, SPA, NM & 3 & I & 0.95 \\
\hline 6. Laguna del Jaral & & Natural Park Doñana, BR, SAC, SPA, NM & 5 & I & 1.01 \\
\hline 7. Torre Carbonero & & WHS, National Park Doñana, BR, SAC, SPA, MN & 5 & I & 1.05 \\
\hline 8. Punta del Boqueron & \multirow{10}{*}{ Cadiz } & Natural Park Bahía de Cadiz, SAC, SPA, NM & 3 & I & 0.98 \\
\hline 9. Playa del Puerco & & Monte Público Dehesa de Roche ** & 2 & I & 1.02 \\
\hline 10. Calas de Roche & & SAC Pinar de Roche & 2 & I & 0.95 \\
\hline 11. Castilnovo & & Complejo Litoral de Interés Ambiental ** & 4 & I & 0.9 \\
\hline 12. Tombolo de Trafalgar & & SAC Punta de Trafalgar, NM & 3 & I & 1.09 \\
\hline 13. Cala de Las Cortinas & & Natural Park La Breña de Barbate, SAC, SPA & 5 & I & 1.15 \\
\hline 14. La Hierbabuena & & Natural Park La Breña de Barbate, SAC, SPA & 1 & I & 0.96 \\
\hline 15. El Cañuelo & & Natural Park Estrecho de Gibraltar, IMBR, SAC, SPA & 4 & I & 1.23 \\
\hline 16. Bolonia & & Natural Park Estrecho de Gibraltar, IMBR, SAC, SPA & 2 & I & 1.11 \\
\hline 17. El Lentiscal & & Natural Park Estrecho de Gibraltar, IMBR, SAC, SPA & 3 & I & 1.09 \\
\hline
\end{tabular}


Table 1. Cont.

\begin{tabular}{|c|c|c|c|c|c|}
\hline MAP NUMBER \& SITE & $\mathbf{P}$ & PROTECTION FEATURE & A.D.* & CLASS & D \\
\hline 18. Punta de la Morena & & Natural Park Estrecho de Gibraltar, IMBR, SAC, SPA & 4 & I & 1.05 \\
\hline 19. El Chorrito de la Teja & & Natural Park Estrecho de Gibraltar, IMBR, SAC, SPA & 4 & I & 1.06 \\
\hline 20. Valdevaqueros & & Natural Park Estrecho de Gibraltar, IMBR, SAC, SPA & 1 & I & 0.91 \\
\hline 21. Lances Norte & & Natural Place Estrecho de Gibraltar, IMBR, SAC, SPA & 3 & II & 0.8 \\
\hline 22. Ensenada del Tolmo & & Natural Park Estrecho de Gibraltar, IMBR, SAC, SPA & 5 & II & 0.84 \\
\hline 23. Cala Arena & & Natural Park Estrecho de Gibraltar, IMBR, SAC, SPA & 4 & I & 0.91 \\
\hline 24. Cabopino & \multirow{7}{*}{ Malaga } & NM Dunas de Artola & 1 & II & 0.73 \\
\hline 25. Punta de Vélez & & None & 2 & II & 0.77 \\
\hline 26. Caleta de Maro & & Natural Place Maro-CG, SPAMI, SAC, SPA & 3 & II & 0.84 \\
\hline 27. Cala Chumbo & & Natural Place Maro-CG, SPAMI, SAC, SPA & 5 & $\mathrm{I}$ & 1.02 \\
\hline 28. Las Alberquillas & & Natural Place Maro-CG, SPAMI, SAC, SPA & 3 & I & 0.95 \\
\hline 29. Calas del Pino & & Natural Place Maro-CG, SPAMI, SAC, SPA & 3 & I & 0.95 \\
\hline 30. Cala el Cañuelo & & Natural Place Maro-CG, SPAMI, SAC, SPA & 3 & I & 0.9 \\
\hline 31. Cantarrijan & \multirow{4}{*}{ Granada } & Natural Place Maro-CG, SPAMI, SAC, SPA & 2 & I & 1.07 \\
\hline 32. Cala El Cambron & & SAC Acantilados y Fondos marinos de Tesorillo-Salobreña & 3 & II & 0.68 \\
\hline 33. La Rijana & & SAC Acantilados y F. Marinos Calahonda & 2 & $\mathrm{I}$ & 0.89 \\
\hline 34. El Ruso & & None & 4 & $\mathrm{I}$ & 0.96 \\
\hline 35. Punta Sabinar & \multirow{16}{*}{ Almeria } & Natural Place Punta Entinas-Sabinar, SCI, SPA & 4 & II & 0.82 \\
\hline 36. Cala Arena & & Natural Park Cabo de Gata-Nijar, BR, SPAMI, SAC, SPA, EGN & 3 & $\mathrm{I}$ & 0.96 \\
\hline 37. Cala Raja & & Natural Park Cabo de Gata-Nijar, BR, SPAMI, SAC, SPA, EGN & 3 & I & 1.04 \\
\hline 38. Cala de la Media Luna & & Natural Park Cabo de Gata-Nijar, BR, SPAMI, SAC, SPA, EGN & 2 & I & 1.01 \\
\hline 39. Monsul & & Natural Park Cabo de Gata-Nijar, BR, SPAMI, SAC, SPA, EGN & 2 & I & 1.19 \\
\hline 40. Barronal & & Natural Park Cabo de Gata-Nijar, BR, SPAMI, SAC, SPA, EGN & 3 & I & 1.03 \\
\hline 41. Cala Grande & & Natural Park Cabo de Gata-Nijar, BR, SPAMI, SAC, SPA, EGN & 4 & I & 1.09 \\
\hline 42. Los Genoveses & & Natural Park Cabo de Gata-Nijar, BR, SPAMI, SAC, SPA, EGN & 2 & I & 1.26 \\
\hline 43. El Playazo & & Natural Park Cabo de Gata-Nijar, BR, SPAMI, SAC, SPA, EGN & 2 & I & 1.12 \\
\hline 44. Cala de San Pedro & & Natural Park Cabo de Gata-Nijar, BR, SPAMI, SAC, SPA, EGN & 5 & I & 0.85 \\
\hline 45. Cala del Plomo & & Natural Park Cabo de Gata-Nijar, BR, SPAMI, SAC, SPA, EGN & 2 & I & 0.91 \\
\hline 46. Cala de Enmedio & & Natural Park Cabo de Gata-Nijar, BR, SPAMI, SAC, SPA, EGN & 4 & I & 1.2 \\
\hline 47. Los Muertos & & Natural Park Cabo de Gata-Nijar, BR, SPAMI, SAC, SPA, EGN & 3 & I & 0.93 \\
\hline 48. El Sombrerico & & SAC Sierra Cabrera-Bedar, SPAMI Fondos mar. lev. almeriense & 2 & I & 0.88 \\
\hline 49. Bordenares & & SAC Sierra Cabrera-Bedar, SPAMI Fondos mar. lev. almeriense & 2 & I & 0.94 \\
\hline 50. Los Cocedores & & None, marine area protected as SPAMI & 1 & II & 0.83 \\
\hline
\end{tabular}

\section{Methodology}

\subsection{Preamble}

The technique is semi-quantitative and it tends to eliminate subjectivity and is based upon a wealth of information collected from beach users giving a sound data base, on which to make effective management decisions. Many other scenic assessments have been made based upon subjective analyses, but few acknowledge the implications of subjectivity on the validity of the results [58]. 'Any assessment of coastal quality is likely to meet with criticism,' alas a comment true in 2018 [59] (p. 7)! also It was also argued that, 'nature affects our minds as light affects a photographic emulsion on a film. Some films are more sensitive than others, some minds are more receptive.' [60] (p. 72). It is acknowledged that further work is needed, as at the moment, the technique is very much a western world approach to scenery. For example, Polynesia and Asia inhabitants might have differing views on some of the parameters, especially as China is expected to become the largest outbound market in terms of visitor numbers in the next few years.

\subsection{Methodology Used}

The methodology used was an outcome of an investigation financed by the British Council [61], which was subsequently rewritten and published [20]. A detailed description can be found in [20]. The question 'what do they perceive as being the essential parameters that make up a beautiful coastal scene' and the converse, 'coastal ugliness', was asked to $>1000$ beach users chosen from random number tables in Malta, Turkey, and the UK, which gave rise to a large data base with a standard 
error of 0.03. Agreement of opinion from this cohort-all geared to their personal perception of coastal scenery, allows for a consensus to form as to what constitutes a beautiful coastal scene and its converse an ugly scene. There is nothing wrong in any one individual's subjective evaluation of a given landscape, but for management purposes the opinions of many people-lay people, experts are required, as viewpoints from many individuals tend to conform to the required real and objective consideration. A good agreement between European nationality tourist groups with regard to the most/least preferred landscapes/scenery exist [62]. Replies to the posed question were varied but overwhelmingly 26 parameters-18 physical and eight human stood out from the rest and were utilised in a checklist [20].

After detailed discussion with other coastal experts, attributes to each of the 26 parameters (y axis) were given a value on the $x$ axis ranging from a low (1) to high rating (5, Table 2). This was field tested with beach users, e.g., if higher cliffs were in the locality then the cliff scenery attribute was ranked better; similarly, tourists prefer a white/golden sand beach than a dark one [63]. Authors proved this point in a detailed study of Cuban beaches [64].

Additional beach surveys $(n \geq 500)$ were carried out in the same countries to rank the above parameters from most to least important as all of the parameters are NOT equal, some being more important than others and a weighting component was introduced (Table 3). Lastly, Fuzzy Logic Assessment (FLA) [65], which is a scientific approach where uncertainties in judgment are covered for all possible distributions [66], was used to eliminate the possibility of the scenic value assessor (who ticks one box for each parameter of the checklist-Table 2), ticking the wrong attribute box. For example, cliff slope can be: $<45^{\circ}$ (score 1 ), $45^{\circ}-60^{\circ}, 60^{\circ}-75^{\circ}, 75^{\circ}-85^{\circ}$ and circa vertical (score 5 , Table 2) and FLA overcomes the problem of the wrong attribute being selected and placed in the checklist box, i.e., a cliff slope being recorded in the $<45^{\circ}$ box, when in fact it was c. $70^{\circ}$ (see corrections coefficients in Table 2). It is extremely unlikely that a jump of two attributes would take place. Assessors for the 50 sites that are investigated for this paper were expert coastal geomorphologists and have had much experience in using the technique in European and South American locations $[28,31,67,68]$. Assessment matrices were obtained for all of the investigated sites and presented as histograms, membership degree and weighted average of attributes $[27,28]$. Histograms provided immediate visual assessment of high and low rated parameters. The membership degree vs. attribute curve gave an overall scenic assessment. Curve explanation is based on the skew: a curve skewed to the right reflects high scenic qualities due to low scoring on attributes 1 and 2, and vice versa for a left hand skew. Weighted averages allowed visual comparison of physical and human parameters. According to the above summed parameter evaluations, a final evaluation index (D) is calculated, which divides coastal scenery into five distinct classes, from Class I (extremely attractive natural sites) to Class V (very unattractive, intensively developed urban sites). Chi square and Kolmagorov-Smirnov testing at the 0.05 significance level showed the normality of the break point distributions, indicating robustness in the technique. 
Table 2. Coastal Scenic Evaluation checklist.

\begin{tabular}{|c|c|c|c|c|c|c|}
\hline \multirow{2}{*}{ No. } & \multirow{2}{*}{ PARAMETERS } & \multicolumn{5}{|c|}{ RATING } \\
\hline & & 1 & 2 & 3 & 4 & 5 \\
\hline 1 & Height $(H)$ & Absent & $5 \mathrm{~m} \leq H<30 \mathrm{~m}$ & $30 \mathrm{~m} \leq H<60 \mathrm{~m}$ & $60 \mathrm{~m} \leq H<90 \mathrm{~m}$ & $H \geq 90 \mathrm{~m}$ \\
\hline 2 & Slope & $<45^{\circ}$ & $45^{\circ}-60^{\circ}$ & $60^{\circ}-75^{\circ}$ & $75^{\circ}-85^{\circ}$ & circa vertical \\
\hline 3 & Features * & Absent & 1 & 2 & 3 & Many $(>3)$ \\
\hline 4 & Type & Absent & Mud & Cobble/Boulder & Pebble/Gravel & Sand \\
\hline 5 & BEACH FACE & Absent & $\mathrm{W}<5 \mathrm{~m}$ or $\mathrm{W}>100 \mathrm{~m}$ & $5 \mathrm{~m} \leq W<25 \mathrm{~m}$ & $25 \mathrm{~m} \leq W<50 \mathrm{~m}$ & $50 \mathrm{~m} \leq W \leq 100 \mathrm{~m}$ \\
\hline 6 & Colour & Absent & Dark & Dark tan & Light tan/bleached & White/gold \\
\hline 7 & Slope & Absent & $<5^{\circ}$ & $5^{\circ}-10^{\circ}$ & $10^{\circ}-20^{\circ}$ & $20^{\circ}-45^{\circ}$ \\
\hline 8 & ROCKY SHORE & Absent & $<5 \mathrm{~m}$ & $5-10 \mathrm{~m}$ & $10-20 \mathrm{~m}$ & $>20 \mathrm{~m}$ \\
\hline 9 & Roughness & Absent & Distinctly jagged & Deeply pitted and/or irregular & Shallow pitted & Smooth \\
\hline 10 & DUNES & Absent & Remnants & Fore-dune & Secondary ridge & Several \\
\hline 11 & VALLEY & Absent & Dry valley & $(<1 \mathrm{~m})$ Stream & $(1-4 \mathrm{~m})$ Stream & River/limestone gorge \\
\hline 12 & SKYLINE LANDFORM & Not visible & Flat & Undulating & Highly undulating & Mountainous \\
\hline 13 & TIDES & Macro (>4 m) & & Meso $(2-4 \mathrm{~m})$ & & Micro $(<2 \mathrm{~m})$ \\
\hline 14 & COASTAL LANDSCAPE FEATURES ** & None & 1 & 2 & 3 & $>3$ \\
\hline 15 & VISTAS & Open on one side & Open on two sides & & Open on three sides & Open on four sides \\
\hline 16 & WATER COLOUR \& CLARITY & Muddy brown/grey & Milky blue/green/opaque & Green/grey/blue & Clear blue/dark blue & Very clear turquoise \\
\hline 17 & NATURAL VEGETATION COVER & Bare ( $<10 \%$ vegetation only) & $\begin{array}{c}\text { Scrub/garigue } \\
\text { (marran/gorse, bramble, etc.) }\end{array}$ & Wetlands/meadow & $\begin{array}{c}\text { Coppices, maquis ( } \pm \text { mature } \\
\text { trees) }\end{array}$ & $\begin{array}{c}\text { Varity of mature } \\
\text { trees/mature natural cover }\end{array}$ \\
\hline 18 & VEGETATION DEBRIS & Continuous (>50 cm high) & Full strand line & Single accumulation & Few scattered items & None \\
\hline 19 & NOISE DISTURBANCE & Intolerable & Tolerable & & Little & None \\
\hline 20 & LITTER & Continuous accumulations & Full strand line & Single accumulation & Few scattered items & Virtually absent \\
\hline 21 & SEWAGE DISCHARGE EVIDENCE & Sewage evidence & & Same evidence (1-3 items) & & No evidence of sewage \\
\hline 22 & NON_BUILT ENVIRONMENT & None & & Hedgerow/terracing/monoculture & & $\begin{array}{c}\text { Field mixed cultivation } \pm \\
\text { trees/natural }\end{array}$ \\
\hline 23 & BUILT ENVIRONMENT *** & Heavy Industry & Heavy tourism and/or urban & $\begin{array}{l}\text { Light tourism and/or urban } \\
\text { and/or sensitive }\end{array}$ & $\begin{array}{l}\text { Sensitive tourism and/or } \\
\text { urban }\end{array}$ & Historic and/or none \\
\hline 24 & ACCESS TYPE & $\begin{array}{l}\text { No buffer zone/heavy } \\
\text { traffic }\end{array}$ & No buffer zone/light traffic & & $\begin{array}{l}\text { Parking lot visible from } \\
\text { coastal area }\end{array}$ & $\begin{array}{l}\text { Parking lot not visible from } \\
\text { coastal area }\end{array}$ \\
\hline 25 & SKYLINE & Very unattractive & & Sensitively designed high/low & Very sensitively designed & Natural/historic features \\
\hline 26 & UTILITIES **** & $>3$ & 3 & 2 & 1 & None \\
\hline
\end{tabular}


Table 3. Fuzzy Logic Matrix for Torre del Loro (Huelva).

\begin{tabular}{|c|c|c|c|c|c|c|c|c|c|c|c|c|c|c|c|c|c|c|c|c|c|}
\hline \multirow{4}{*}{ No. } & \multirow{4}{*}{\multicolumn{2}{|c|}{ Assessment Parameters }} & \multirow{4}{*}{$\begin{array}{c}\text { Graded } \\
\text { Attributes }\end{array}$} & \multirow{4}{*}{$\begin{array}{l}\text { Weights of } \\
\text { Parameters }\end{array}$} & \multirow{4}{*}{\multicolumn{5}{|c|}{ Input Matrices $d_{i}$}} & \multicolumn{12}{|c|}{ Fuzzy Assessment Matrices } \\
\hline & & & & & & & & & & \multirow{3}{*}{ G Matrices } & \multirow{2}{*}{\multicolumn{5}{|c|}{$\begin{array}{c}\text { Grade Matrices } \mathrm{G}_{\mathrm{i}} \\
\text { Attributes (1-5) }\end{array}$}} & \multirow{3}{*}{ R Matrices } & \multirow{2}{*}{\multicolumn{5}{|c|}{$\begin{array}{c}\text { Fuzzy Weighted Assessment } \\
\text { Matrix } R_{m}\end{array}$}} \\
\hline & & & & & & & & & & & & & & & & & & & & & \\
\hline & & & & & & & & & & & 1 & 2 & 3 & 4 & 5 & & 1 & 2 & 3 & 4 & 5 \\
\hline 1 & & Cliff Height & 2 & 0.019 & 0 & 1 & 0 & 0 & 0 & & 0.00 & 1.00 & 0.30 & 0.00 & 0.00 & & 0.000 & 0.019 & 0.006 & 0.000 & 0.000 \\
\hline 2 & & Cliff Slope & 3 & 0.017 & 0 & 0 & 1 & 0 & 0 & & 0.00 & 0.50 & 1.00 & 0.50 & 0.00 & & 0.000 & 0.009 & 0.017 & 0.009 & 0.000 \\
\hline 3 & \multirow{16}{*}{ PHYSICAL } & Special Features & 4 & 0.028 & 0 & 0 & 0 & 1 & 0 & \multirow{16}{*}{$\mathrm{G}_{\mathrm{P}}$} & 0.00 & 0.00 & 0.00 & 1.00 & 0.30 & \multirow{16}{*}{$\mathrm{R}_{\mathrm{P}}$} & 0.000 & 0.000 & 0.000 & 0.028 & 0.008 \\
\hline 4 & & Beach Type & 5 & 0.034 & 0 & 0 & 0 & 0 & 1 & & 0.00 & 0.00 & 0.00 & 0.00 & 1.00 & & 0.000 & 0.000 & 0.000 & 0.000 & 0.034 \\
\hline 5 & & Beach Width & 4 & 0.029 & 0 & 0 & 0 & 1 & 0 & & 0.00 & 0.00 & 0.20 & 1.00 & 0.60 & & 0.000 & 0.000 & 0.006 & 0.029 & 0.017 \\
\hline 6 & & Beach Color & 5 & 0.024 & 0 & 0 & 0 & 0 & 1 & & 0.00 & 0.00 & 0.00 & 0.00 & 1.00 & & 0.000 & 0.000 & 0.000 & 0.000 & 0.024 \\
\hline 7 & & Shore Slope & 1 & 0.014 & 1 & 0 & 0 & 0 & 0 & & 1.00 & 0.00 & 0.00 & 0.00 & 0.00 & & 0.014 & 0.000 & 0.000 & 0.000 & 0.000 \\
\hline 8 & & Shore Extent & 1 & 0.015 & 1 & 0 & 0 & 0 & 0 & & 1.00 & 0.00 & 0.00 & 0.00 & 0.00 & & 0.015 & 0.000 & 0.000 & 0.000 & 0.000 \\
\hline 9 & & Shore roughness & 1 & 0.022 & 1 & 0 & 0 & 0 & 0 & & 1.00 & 0.00 & 0.00 & 0.00 & 0.00 & & 0.022 & 0.000 & 0.000 & 0.000 & 0.000 \\
\hline 10 & & Dunes & 5 & 0.039 & 0 & 0 & 0 & 0 & 1 & & 0.00 & 0.00 & 0.00 & 0.00 & 1.00 & & 0.000 & 0.000 & 0.000 & 0.000 & 0.039 \\
\hline 11 & & Valley & 1 & 0.079 & 1 & 0 & 0 & 0 & 0 & & 1.00 & 0.00 & 0.00 & 0.00 & 0.00 & & 0.079 & 0.000 & 0.000 & 0.000 & 0.000 \\
\hline 12 & & Landform & 1 & 0.085 & 1 & 0 & 0 & 0 & 0 & & 1.00 & 0.20 & 0.00 & 0.00 & 0.00 & & 0.085 & 0.017 & 0.000 & 0.000 & 0.000 \\
\hline 13 & & Tides & 3 & 0.036 & 0 & 0 & 1 & 0 & 0 & & 0.00 & 0.00 & 1.00 & 0.00 & 0.00 & & 0.000 & 0.000 & 0.036 & 0.000 & 0.000 \\
\hline 14 & & Landscape Features & 4 & 0.122 & 0 & 0 & 0 & 1 & 0 & & 0.00 & 0.00 & 0.00 & 1.00 & 0.20 & & 0.000 & 0.000 & 0.000 & 0.121 & 0.024 \\
\hline 15 & & Vistas & 4 & 0.095 & 0 & 0 & 0 & 1 & 0 & & 0.00 & 0.00 & 0.00 & 1.00 & 0.30 & & 0.000 & 0.000 & 0.000 & 0.095 & 0.029 \\
\hline 16 & & Water Color & 4 & 0.139 & 0 & 0 & 0 & 1 & 0 & & 0.00 & 0.00 & 0.50 & 1.00 & 0.20 & & 0.000 & 0.000 & 0.070 & 0.140 & 0.028 \\
\hline 17 & & Vegetation Cover & 4 & 0.117 & 0 & 0 & 0 & 1 & 0 & & 0.00 & 0.00 & 0.20 & 1.00 & 0.20 & & 0.000 & 0.000 & 0.023 & 0.117 & 0.023 \\
\hline 18 & & Seaweed & 4 & 0.086 & 0 & 0 & 0 & 1 & 0 & & 0.00 & 0.00 & 0.20 & 1.00 & 0.00 & & 0.000 & 0.000 & 0.017 & 0.086 & 0.000 \\
\hline 19 & \multirow{8}{*}{ HUMAN } & Disturbance Factor & 5 & 0.137 & 0 & 0 & 0 & 0 & 1 & \multirow{8}{*}{$\mathrm{G}_{\mathrm{H}}$} & 0.00 & 0.00 & 0.00 & 0.20 & 1.00 & \multirow{8}{*}{$\mathrm{R}_{\mathrm{H}}$} & 0.000 & 0.000 & 0.000 & 0.027 & 0.137 \\
\hline 20 & & Litter & 3 & 0.149 & 0 & 0 & 1 & 0 & 0 & & 0.00 & 0.20 & 1.00 & 0.20 & 0.00 & & 0.000 & 0.030 & 0.149 & 0.030 & 0.000 \\
\hline 21 & & Sewage & 5 & 0.149 & 0 & 0 & 0 & 0 & 1 & & 0.00 & 0.00 & 0.20 & 0.00 & 1.00 & & 0.000 & 0.000 & 0.030 & 0.000 & 0.149 \\
\hline 22 & & Non-built Environment & 5 & 0.064 & 0 & 0 & 0 & 0 & 1 & & 0.00 & 0.00 & 0.20 & 0.00 & 1.00 & & 0.000 & 0.000 & 0.013 & 0.000 & 0.064 \\
\hline 23 & & Built Environment & 5 & 0.137 & 0 & 0 & 0 & 0 & 1 & & 0.00 & 0.00 & 0.00 & 0.00 & 1.00 & & 0.000 & 0.000 & 0.000 & 0.000 & 0.137 \\
\hline 24 & & Access Type & 5 & 0.091 & 0 & 0 & 0 & 0 & 1 & & 0.00 & 0.00 & 0.00 & 0.20 & 1.00 & & 0.000 & 0.000 & 0.000 & 0.018 & 0.091 \\
\hline 25 & & Skyline & 5 & 0.137 & 0 & 0 & 0 & 0 & 1 & & 0.00 & 0.00 & 0.00 & 0.00 & 1.00 & & 0.000 & 0.000 & 0.000 & 0.000 & 0.137 \\
\hline 26 & & Utilities & 5 & 0.137 & 0 & 0 & 0 & 0 & 1 & & 0.00 & 0.00 & 0.00 & 0.20 & 1.00 & & 0.000 & 0.000 & 0.000 & 0.027 & 0.137 \\
\hline
\end{tabular}


In this paper, Google images were used in order to give a first approximation of beautiful locations. The images were basically used to eliminate urban areas and 62 natural locations were initially selected, but 12 were omitted due to access only by boat or via a long walk (i.e., more than $1.5 \mathrm{~h}$ ). Consequently, field visits were planned to choose and survey what appeared to be only natural and attractive sites (Classes I and II), irrespective as to whether they were located in protected areas or not. The sites were then field tested by the itemised checklist technique.

Their distribution ranged greatly according to their scenic beauty and landscape variety, i.e., a greater spatial density was applied in non-homogeneous areas. Once sites were selected, scenic field evaluations were carried out by the authors. The checklist was filled by expert assessors between 10 a.m. and 5 p.m. under normal summer weather conditions (June and September 2016) when stable conditions ruled e.g., no storms that could influence water colour for the site and over a $100 \mathrm{~m}$ range along the site ticking off relevant parameter boxes, which allowed for the determination of the site state according to its current attributes. Discussion was encouraged on each parameter regarding its attribute value. This gives a more accurate assessment. Other information was also gathered regarding site location, protection feature, beach award status, and tourist development typologies and distribution [21,22].

\section{Protected Areas}

Thirty-five percent of the $910 \mathrm{~km}$ of Andalusia coast are under some form of protection and $88 \%$ of the investigated sites are located in protected areas. RENPA is the Andalusia environmental agency that deals with all of the issues related to the establishment and management of all protected areas-established at international, national, and regional level.

In Andalusia, the most common protection form at international level is the Natura 2000 Network, which includes Sites of Community Importance (SCI), this is an initial stage establishment of a protected area and after a variable time is transformed to a Special Area of Conservation (SAC) that was established under the Habitat Directive, and Special Protection Area for birds (SPA) established under the Bird Directive. At the national level, five features of protection (parks, natural reserves, marine protected areas, natural monument, and protected landscapes), were established by the Law 42/2007 "Natural Heritage and Biodiversity" and their level of protection ranges a lot from one to another. National Parks have the strictest regulations. Natural parks, which are numerous along the coast of Andalusia (Table 1), allow some kind of human activities and settlements. Marine protected areas are specifically established to protect marine ecosystems of great relevance. Natural monuments are established to preserve special and singular places/areas because of their geological or biological characteristics; examples along the study area are the cliff at El Asperillo (Huelva), Punta del Boquerón and Tombolo de Tarifa (Cadiz) and dunes at Cabopino (Malaga). At the regional level, Natural Place is a protection form that is established by the Andalusia parliament to preserve areas of special importance because of its biological or geomorphologic importance and beauty.

Figure 2 shows the different protection forms observed at the investigated sites. Most of the sites are protected under the Natura 2000 Network (i.e., SCI, SAC, and SPA, Table 1), international features (i.e., World Heritage Site, Biosphere Reserve, SPAMI, and European Geopark Network, Table 1), and National and Autonomous legislations (e.g., National and Natural Parks, Natural Place and Natural Monument). Doñana is 1 (out of 14) National parks existing in Spain and is also an UNESCO area. Four of the nine Specially Protected Areas of Mediterranean Importance located in Spain, are observed along the study area (Table 1 ).

The distribution of protected areas and associated investigated sites is not uniform (Table 1): most sites belong to the Natural Park Cabo de Gata-Nijar (24\%), the Natural Park Estrecho de Gibraltar (18\%) and the Natural Place Acantilado de Maro-Cerro Gordo (12\%) and the Natural and National parks of Doñana ( $8 \%$ ). Almeria and Cadiz are the provinces with the most numerous level of investigated sites, followed by Malaga and Granada; in Malaga province, along the $185 \mathrm{~km}$ Costa del Sol coast only two sites are observed, i.e., Velez and Cabopino, respectively, at 47 and 49 positions in the regional ranking. 
The poverty of scenic value in Costa del Sol is due to the heavy urbanization that has been recorded since the 1970s that produced the destruction of natural habitats [51].

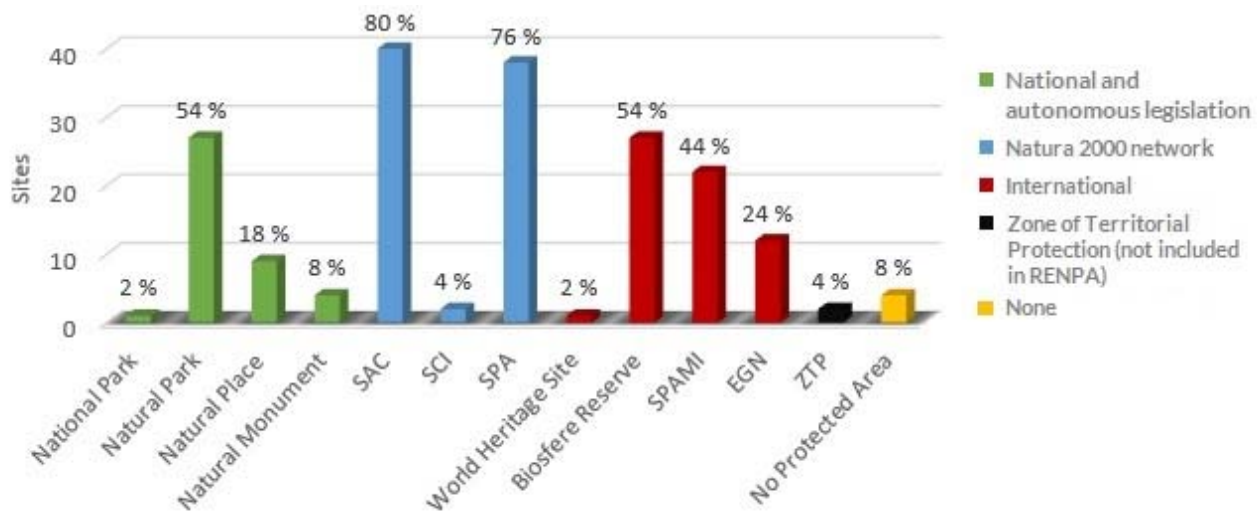

Figure 2. Protection features of the investigated sites (see Table 1 for details).

\section{Management Models}

The main aims of this paper were the characterization of coastal scenic value at the investigated sites and the proposal of sound management strategies to maintain or to improve the site's scenic value, along with the associated ecotourism and sustainable nature-based tourism [69]. Sustainable tourism guidelines take into account the current and future economic, social, and environmental impacts, and this is applicable to all forms of tourism [70], including ecotourism [20]. The United Nations Environment Programme, the International Union for Conservation of Nature, the UN World Tourism Organization (UNWTO), the Global Sustainable Tourism Council, are the most important examples of organizations that consider ecotourism an instrument to conservation, which has positive economic impacts in both the public and private sectors [50]. Results presented constitute a first preliminary attempt and can be used by the RENPA and local and regional managers to establish a Coastal Heritage Site model to further preserve existing (or promote new) pristine and high scenic sites in the respect of the environment. This paper is a first step in this direction and will constitute a base for the establishment of a touristic guide of most attractive scenic sites in Andalusia. To protect and enhance coastal heritage sites is of great relevance [71]:

(a) to identify the finest stretches of undeveloped coast;

(b) to conserve scenic quality and foster leisure activities related to natural scenery and not on man made activities;

(c) to support the sustainable use of the coast for public recreation; and,

(d) to foster users awareness and understanding of conservation by maintaining and improving community involvement.

At many of the investigated sites, conflict really arises between the conservation and recreational activities. Many visitors come at investigated sites only for foreshore recreation, unaware or heedless of the functioning of the protected areas. Landscape and ecological factors are of paramount importance in zoning policies, e.g., along protected areas of the Glamorgan Heritage Coast, Wales, UK [71] and two types of use can be distinguished:

- Intensive. These are the "honeypot" areas, where facilities provided are sufficient and designed to give the minimum effect on the beauty of the protected area but facilitate maximum public enjoyment; and,

- $\quad$ Remote. The aim is to retain areas in a relatively inaccessible and untouched state. This protects fragile habitats from vehicles and people and provides enjoyment to people (i.e., walkers) who like solitude and an absence of vehicles. 
Both of the models are observed (and often coexist) at the Andalusia investigated sites, which are under different forms of protection and/or show different types of management under the same protection status. All of Andalusia's protected areas are administrated according to two main basic tools, i.e., the Plan of Management of Natural Recourses (Plan de Ordenación de los Recursos Naturales, PORN, in Spanish) and the Master Plan of Administration and Use (Plan Rector de Uso y Gestión, PRUG, in Spanish), both being defined by the Act 4/89. The objectives of PORN are the characterization of present land use activities and natural recourses of a determined area, the suggestion of protection/conservational measures and the development of suitable socio-economic activities. PRUG constitutes the functional tool used by managers in the administration of a protected area. It is a technical document that was created after the establishment of a protected area and strictly regulates all of the activities within it, especially the actions that are linked to the use of natural recourses by an appropriate regulation/limitation of public access to some areas, the promotion of specific investigations plans, etc. Further, various bodies, both statutory (essentially) and voluntary, are concerned with coastal conservation, but such involvement is rarely exclusive and, for most agencies and organizations, coastal conservation is just a part of a wider environmental remit [72]. Along the investigated sites assessment of natural and human parameters make possible recognition and characterisation of those variables that must be managed in a better way to promote scenic value improvement. Regarding coastal management issues, high rated human usage parameters at low attribute values are related to litter presence or unsuitable utilities. Most of the sites have natural parameters for which local coastal managers can do little or nothing to improve their scenic impact, e.g., sewage, so importance should be concerned with assessing ways of upgrading human usage parameters $[28,31]$. This can be achieved by the establishment of the following basic management principles-as observed for the Heritage Coast in Wales [71]:

(a) determination of intensity of use;

(b) management zones based on different intensities;

(c) control of development;

(d) regulation of access;

(e) landscape improvements;

(f) diversification of activities; and,

(g) provision of interpretative services.

\section{Results}

\subsection{Natural and Human General Sites Characteristics}

Result of the scenic analysis (D value) and main characteristics of the fifty investigated sites are presented in Tables 1 and 4. Forty-one sites were included in Class I and nine sites in Class II (Figure 3), and all of the sites (but four) were under any feature of protection and just one site (i.e., Cabopino, Malaga province) showed the Blue Flag Award (Table 1). 


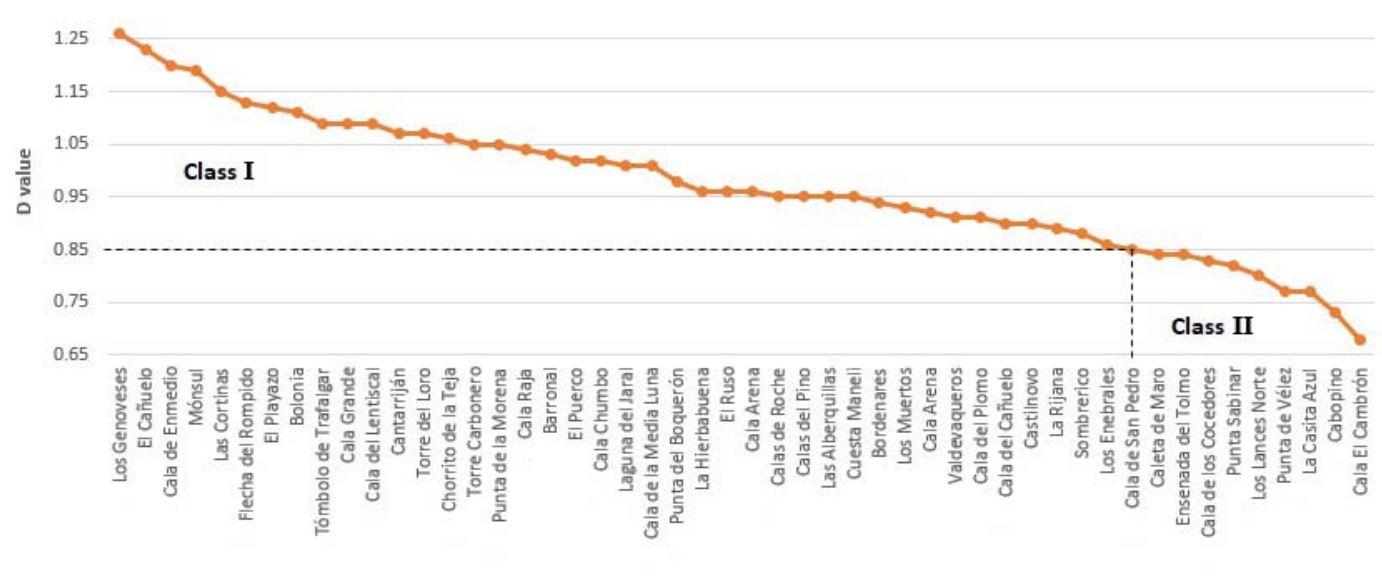

sites

Figure 3. Evaluation index curve for the 50 investigated sites. 
Table 4. Physical and human parameters ratings of the 50 investigated sites, classified by province (P) and protected areas (P.A).

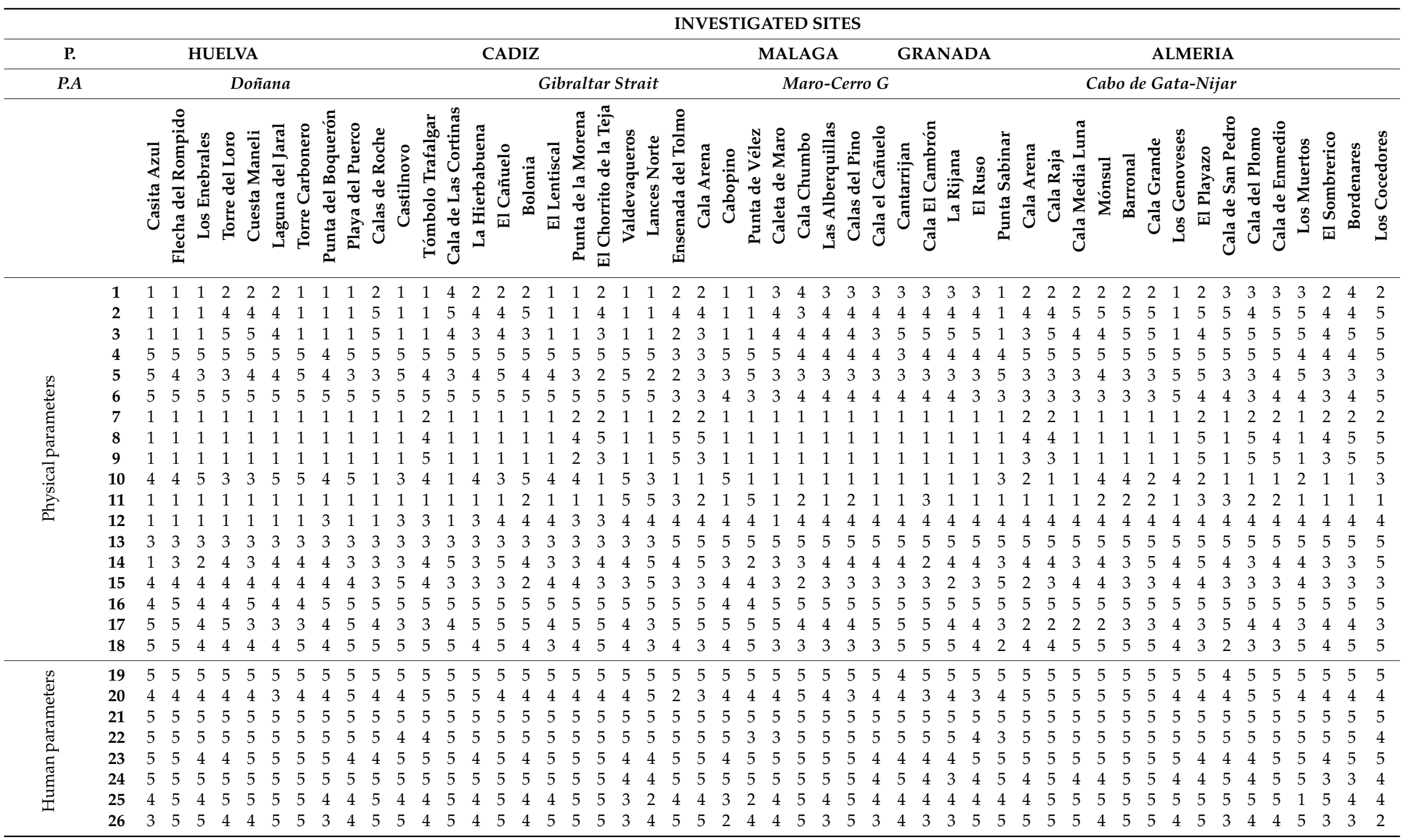


(a). Natural parameters, excellent scenic values are often linked to the geological setting and the presence of mountainous landscapes $[31,67,68]$ essentially related, along the study area, to the Betic Chain that runs parallel to the coast. An undulating landscape is observed at Cabo de Gata and is linked to the Tertiary volcanic relief, which favours the good scores at cliff, rock shore, special features, skyline landform, etc. at several sites that were located in that area (Table 1; Figure 4a, Table 4). Rock shores are essentially observed at the Gibraltar Strait (Figure 4b) and Maro-Cerro Gordo areas and the most important and characteristic cliffs are El Asperillo (an extended cliff feature in Huelva), La Breña (Cadiz), and Maro-Cerro Gordo (Malaga and Granada). El Asperillo cliff, composed of fossil dunes, which is protected under the feature of Natural Monument, is 10-15 m in height and $25 \mathrm{~km}$ in length. It presents gullies, piping, attractive stratification, etc., favouring good scores at several sites, such as Loro, Laguna Jaral, Cuesta Maneli, etc. (Tables 1 and 4). La Breña cliff (Figure 4c), composed by limestones, is c. $100 \mathrm{~m}$ high and shows fractures, evident stratification and small water falls; as a result, high scores are observed at Cortinas and La Hierbabuena sites (Tables 1 and 4). Cliffs at Maro-Cerro Gordo (Figure 4d), which are 30-80 m in height and consist of fractured shales, quartzites, marbles, and limestones, give rise to attractive pocket beaches, e.g., Caleta Maro, Cala Chumbo, Alberquillas, Cala del Pino, and Cantarrijan (Table 1). Good scores at beach characteristics are observed at Huelva and Cadiz provinces and high dunes ennoble natural scenic parameters at Doñana (Figure 4e), Bolonia, and Valdevaqueros (Figure 4f).

(b). Human parameters usually have good scores as almost all places are located in protected areas with null or extremely reduced human impacts (Table 4). It is interesting to highlight as, quite often, the built environment is constituted by historical structures, which obtain a score of 5 ("historic", Table 2). As an example, Vigia towers are observed at 11 sites with particular concentration recorded at Maro-Cerro Gordo where four (out of six) sites have such historical feature (i.e., Alberquillas, Calas del Pino, Cala del Cañuelo, and Cantarriján).
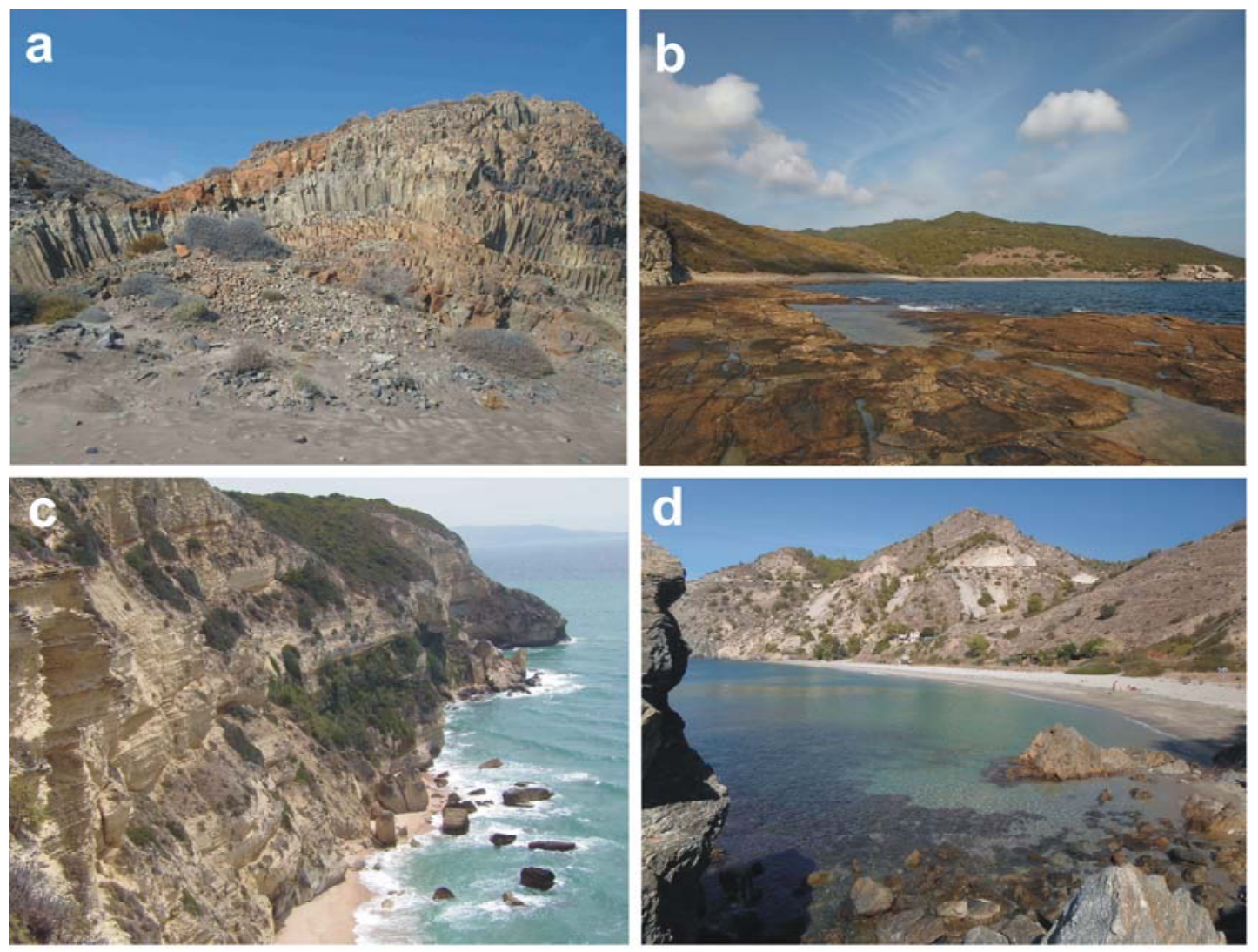

Figure 4. Cont. 

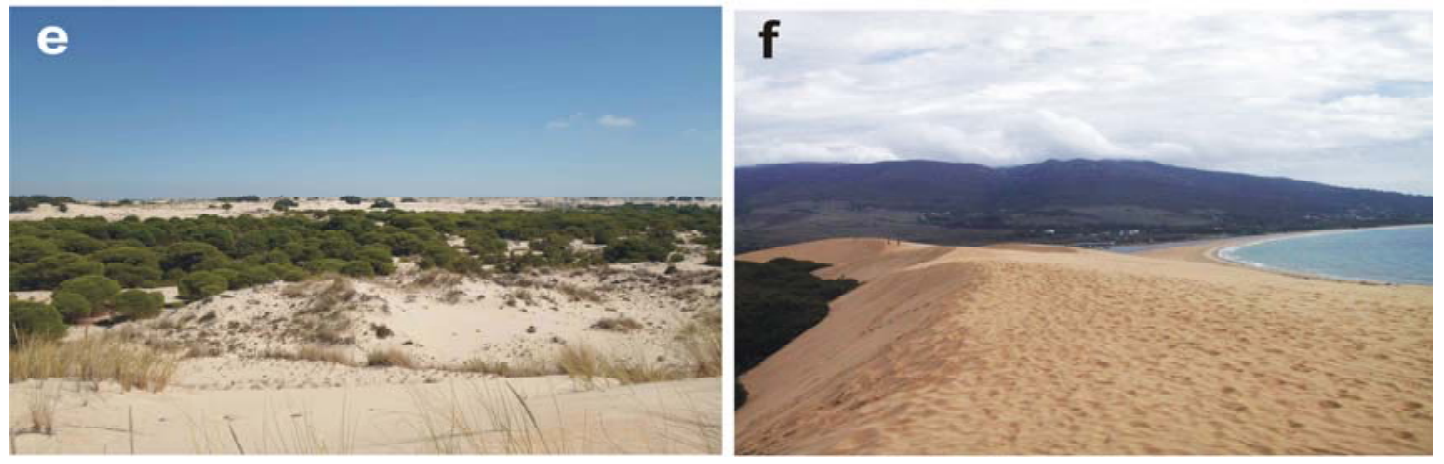

Figure 4. (a) Cliff special features (columnar basalts) at Cala Grande, Natural Park Cabo de Gata-Nijar (Almeria); (b) rock shore platform at Ensenada del Tolmo, Natural Park Estrecho de Gibraltar (Cadiz); (c) high cliffs at Natural Park La Breña de Barbate (Cadiz); (d) cliffs at Natural Place Maro-Cerro Gordo (Malaga) limiting a small pocket beach (Cala El Cañuelo); (e) Vegetated dune ridges at Natural Park of Doñana (Huelva); and, (f) Active dune system at Valdevaqueros (Cadiz).

\subsection{Examples of Class I and II sites}

(a). Class I sites are natural, very attractive areas with a scenic value $\mathrm{D} \geq 0.85$. Several beaches within this class are well-known for their natural beauty and obtained high scores in both physical and human parameters. Forty sites are located in protected areas and one (El Ruso, Granada province) is located in a natural area that has no (or a few) human impacts/structures and distant human constructions (skyline, point 25, Tables 1 and 4) that are not visible from the beach because the site is backed by a c. $40 \mathrm{~m}$ high cliff.

Example of histograms, membership degree vs. attribute curve and weighted averages are presented for two sites, i.e., El Cañuelo (Cadiz province, D: 1.23, ranking: 2) and Cala de la Media Luna (Almeria, D: 1.01, ranking: 21, Table 1). Histograms provided immediate visual assessment of high and low rated parameters (Figure $5 a, b$ ). The membership degree vs. attribute curve gave a curve that was skewed to the right (Figure $6 \mathrm{a}, \mathrm{b}$ ). Weighted averages allowed for the visual comparison of physical and human parameters (Figure $6 \mathrm{a}, \mathrm{b}$ ). Good scores at natural and human parameters were linked to very high intrinsic scenic characteristics and very low human influence.

El Cañuelo is one of the most attractive sites along the Andalusia coast (Figure 3) and is located within the Gibraltar Strait Natural Park (Table 1). This site obtained excellent scores for natural parameters because of the presence of stratified and fractured spectacular cliffs, a large sand beach, foredunes, an highly undulating landscape, abundant vegetation cover, no vegetation debris, very clear turquoise water colour, and especially several landscape features (Figure 5a) that are constituted by headlands and rocky blocks. Human parameters showed maximum scores reflecting the almost negligible human influence (Figure 5a); only a few scattered litter items essentially of marine origin, were observed (score 4 at point 20, Table 2, Figure 5a). The only human construction is an historic lighthouse (score 5 at point 23, Table 2).

Cala de la Media Luna is one out of the twelve beaches located within the Natural Park Cabo de Gata-Nijar (Table 1). Despite the absence of a rocky shore and dunes (score 1 at points 7-10, Table 2) and a dark tan sand colour (score 3, point 6, Table 2), this site showed excellent scores of other natural parameters (Figure 5b), such as cliffs, which are composed of volcanic rocks with an attractive lenticular stratification, highly undulating landscape form, very clear turquoise water colour, absence of vegetation debris, and special landscape features (headlands, rocky blocks, etc.). Almost all human parameters obtained excellent (5) scores (Figure 5b), with a score of 4 being observed at access type (point 24, parking area visible from the beach, Table 2). 
a) El Cañuelo

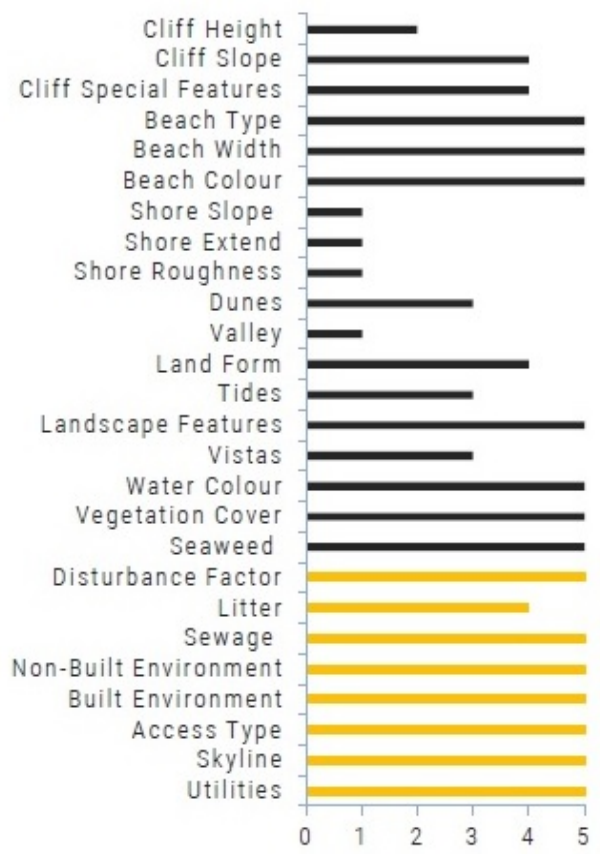

b) Cala de la Media Luna

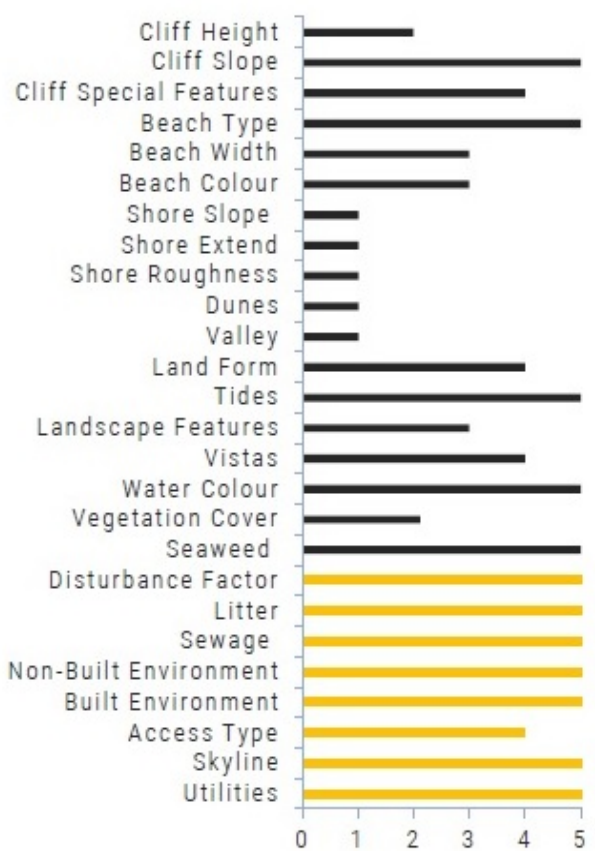

Figure 5. Scenic evaluation rating histograms for El Cañuelo (Class I, Natural Place Maro-Cerro Gordo, Malaga) and Cala de la Media Luna (Class I, Natural Park Cabo de Gata-Nijar, Almeria).

\section{a) El Cañuelo}
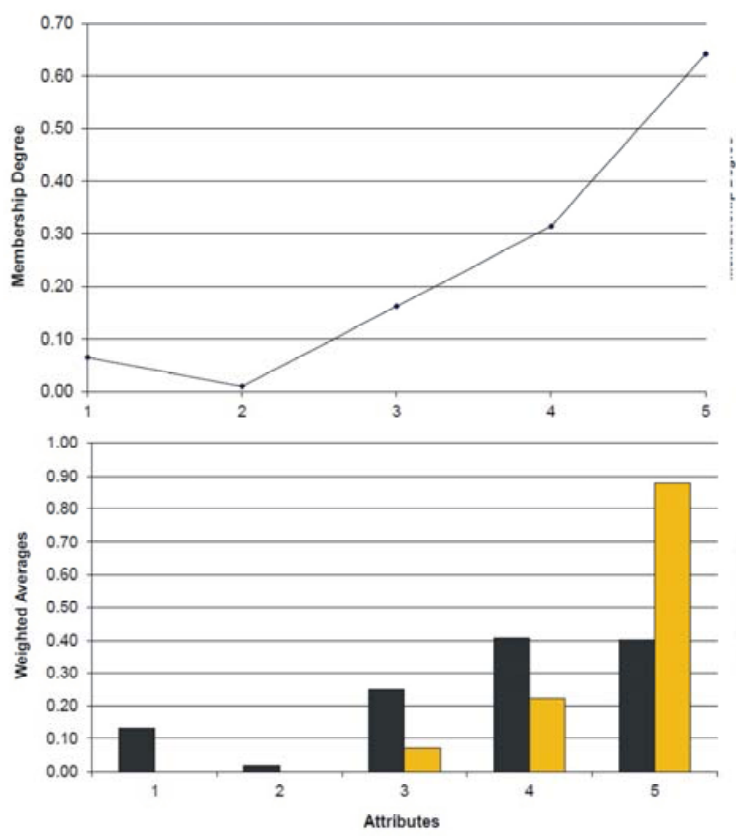

b) Cala de la Media Luna
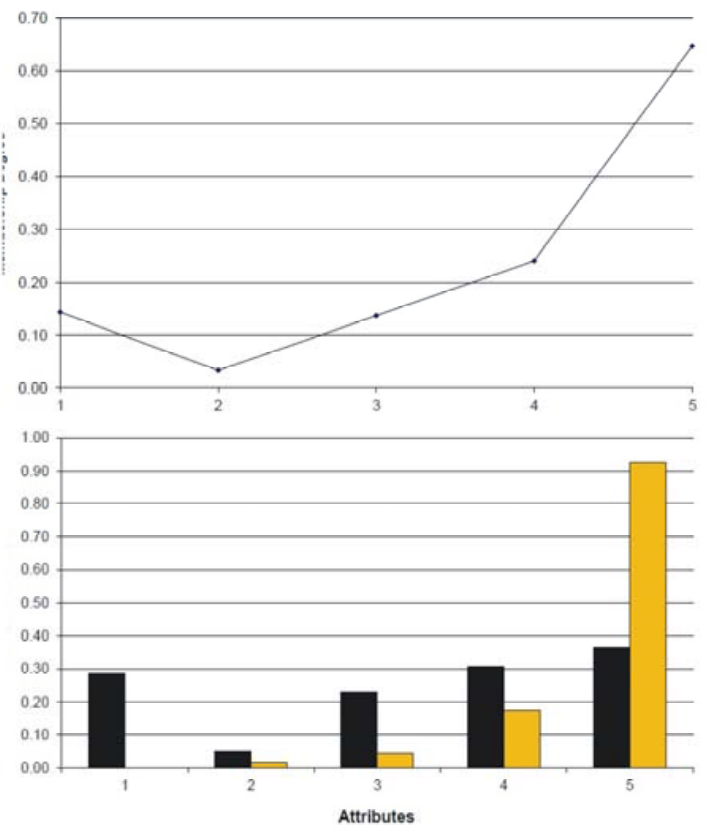

Figure 6. Membership degrees and weighted averages for El Cañuelo (Class I, Natural Place Maro-Cerro Gordo, Malaga) and Cala de la Media Luna (Class I, Natural Park Cabo de Gata-Nijar, Almeria).

(b). Class II sites are constituted by attractive natural areas with high landscape values $(0.65 \leq \mathrm{D}$ $<0.85$ ). Along the investigated coast, nine beaches were classified within this category (Table 1$)$. These sites are usually rated lower than Class I, due to: 
(i) a slightly lower scoring of natural scenic parameters (Figures 7 and 8), because of the absence of mountainous landform and/or special landscape features (e.g., Punta Sabinar, Punta de Velez, Casita Azul, etc., Table 4),

(ii) to lower scores at human parameters (Figures 7 and 8) related to the increase of human activities/impacts (e.g., Cocedores, Ensenada del Tolmo, Lances Norte, etc., Table 4), and

(iii) their location at the borders of protected areas; the skyline is not pristine and nearby human settlements are visible at Los Muertos and Lances Norte. From the former site is visible the industrial harbour of Carboneras and from the latter, human settlements at Tarifa (Table 4).
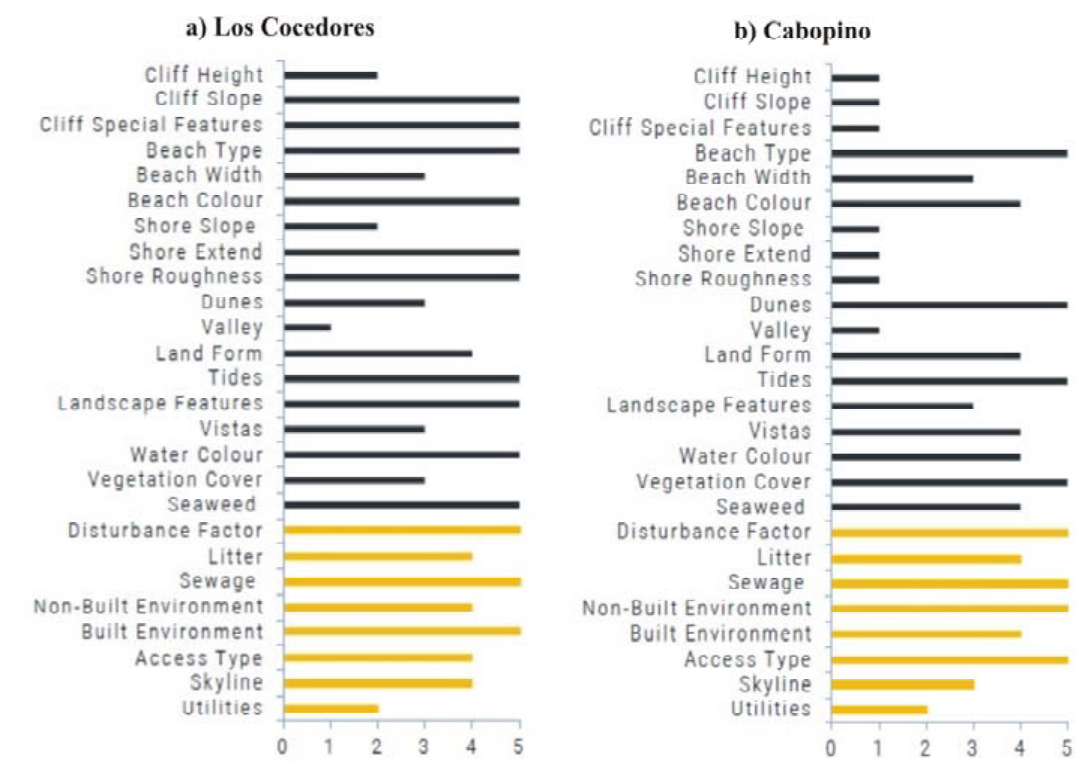

Figure 7. Scenic evaluation rating histograms for Los Cocedores (Class II, Almeria) and Cabopino (Class II, Natural Monument Dunas de Artola, Malaga).

Los Cocedores (Almeria, D: 0.83, ranking: 44, Figure 3, Table 1) shows excellent natural parameters, but only high scores at human ones (Figure 7a).
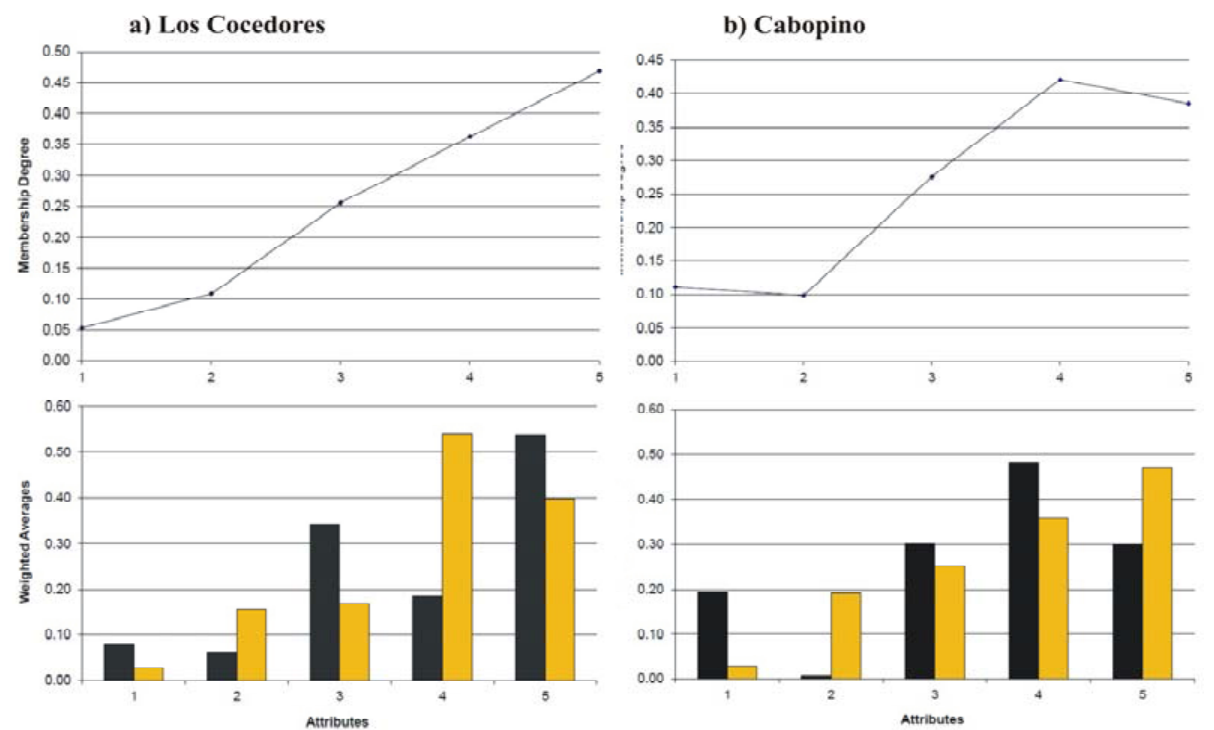

Figure 8. Membership degrees and weighted averages for Los Cocedores (Class II, Almeria) and Cabopino (Class II, Natural Monument Dunas de Artola, Malaga). 
As an example, few scattered litter items abandoned by beach users were observed (score 4, point 20 Table 2), the parking lot is visible from the beach (score 4, point 24, Table 2) and three utilities, i.e., litter bins, a bar, and information panels are observed on the dry beach (score 2, point 26, Table 2). The membership degree vs. attribute curve (Figure 8a) and the weighted averages (Figure 8a) for this site have a trend similar to the one observed for Class I sites, but curve skewness evidences more scores on attribute 3 rather than 4 (for natural parameters), i.e., it increases the natural parameters that score an attribute 3 vs. the ones that scored an attribute 4; similarly, for attributes 4 than 5 for human parameters.

Cabopino (Malaga, D: 0.73, ranking 49, Figure 3, Table 1) presents high scores for natural parameters, e.g., attractive golden fine sands, developed dune ridges and vegetation cover and a highly undulating skyline (Figure $7 \mathrm{~b}$ ). The membership degree vs. attribute curve and the weighted averages (Figure $8 b$ ) for this site have a trend similar to the one observed for Los Cocedores, but curve skewness evidences more scores on attribute 4 rather than 3, and 1 rather than 2 (in both cases for natural parameters). The site is protected under the feature of a Natural Monument especially to preserve the dune system consisting of foredunes, dune ridges and fossil dunes that constitute the remains of the Marbella large dune system that has been destroyed by massive coastal urbanization during the seventies [51]. The skyline is negatively influenced by nearby settlements and a tourist harbour. Several utilities are also present, e.g., bars, facilities and sewerage infrastructures. This is the only site that shows a Blue Flag.

\section{Discussion}

According to the above recommendations, several actions regulated by PORN and PRUG might be carried out at investigated sites to improve the score that was obtained for human parameters (Figure 9). Beach nourishment, formation of artificial dunes, etc., are a few of the small number of changes that can be made to natural parameters; the main management changes have to relate to anthropogenic parameters.

(a). Noise disturbance is usually low, but, at places, a certain disturbance can be observed because of the high number of beach week-end visitors, especially during summer period at sites where beach access is easy, i.e., visitors do not have to walk too far to arrive at the beach (e.g., Bolonia, Calas de Roche, Table 1). These sites are inundated by visitors because of enhanced foreshore attraction (e.g., Valdevaqueros, Los Cocedores, Cala San Pedro) by the presence of bars and kiosks with loud music. As observed in other Mediterranean and Caribbean areas, visitors come to the beach for swimming, sunbathing, to listen to music, and to have 'fun' [73]. The maximum beach carrying capacity $[73,74]$ is sometimes exceeded. Although access to most sites is unrestricted, the problem remains of whether the great affluence and the identified associated need for greater visitor facilities can be reconciled to the maintenance of site interest and diversity. It is a problem regulated by PRUG that can only be resolved by a site-specific approach with careful monitoring of visitor patterns and site degradation [72]. An appropriate management is observed at Cabo de Gata-Níjar and Maro-Cerro Gordo, which implemented a limited access policy and human impacts are very low.

(b). Litter is virtually absent, but, at some remote areas with difficult access, a "full strand line" or "single accumulation" (score 2 and 3, parameter 20, Tables 2 and 4) can be observed). Examples are, Cala Arena and Ensenada del Tolmo (Figure 9a), Laguna del Jaral (Huelva), El Ruso (Figure 9b), and Cambrón (Granada, Tables 1 and 4). Such elevated concentrations, especially of plastics, which occur in abundance in the marine environment and in many remote Mediterranean areas [75-77] are driven by input, long persistence and high floatability [78]. Beach litter is attributed to (essentially) land and (secondarily) marine based-sources [75,79-81]. At investigated sites, litter items are usually not discharged by local beach goers, as observed at urban beaches [82] but transported and stranded by currents and waves. Their accumulation is linked to the absence of periodic cleaning operations due to the difficult of access (impossibility of mechanical clean-ups) together with the low interest of managers. Litter negatively impacts natural wildlife, human health, and activities [83-85], and it is one 
of the five aspects (i.e., safety, facilities, water quality, no litter, and scenery) of the greatest relevance to coastal visitors [21,22]. Litter on a beach is a big turn off for locals and visitors alike. At Ponel de Parana, Brazil, beach litter items amounting to 15 items $/ \mathrm{m}^{2}$ can cause an economic loss ranging from US\$ 3.2 to 8.5 million, resulting in a forfeiture of tourist income of between $15 \%$ to $39 \%$ [86]. The cost of Ponel de Parana beach cleaning (mostly state funded) would represent just $6.2 \%$ of potential economic losses. If periodic cleaning operations at Spanish beaches were established during summer periods and with a greater periodicity in winter, scenic values would increase. For example, the current litter score (3) at Laguna del Jaral (Huelva) would improve to obtain a value of 4 , and the D value would increase from 1.01 to 1.16. At Ensenada del Tolmo (Cadiz), a Class II site (D: 0.84), the establishment of cleaning operations would upgrade the site to Class I (D: 1.07).
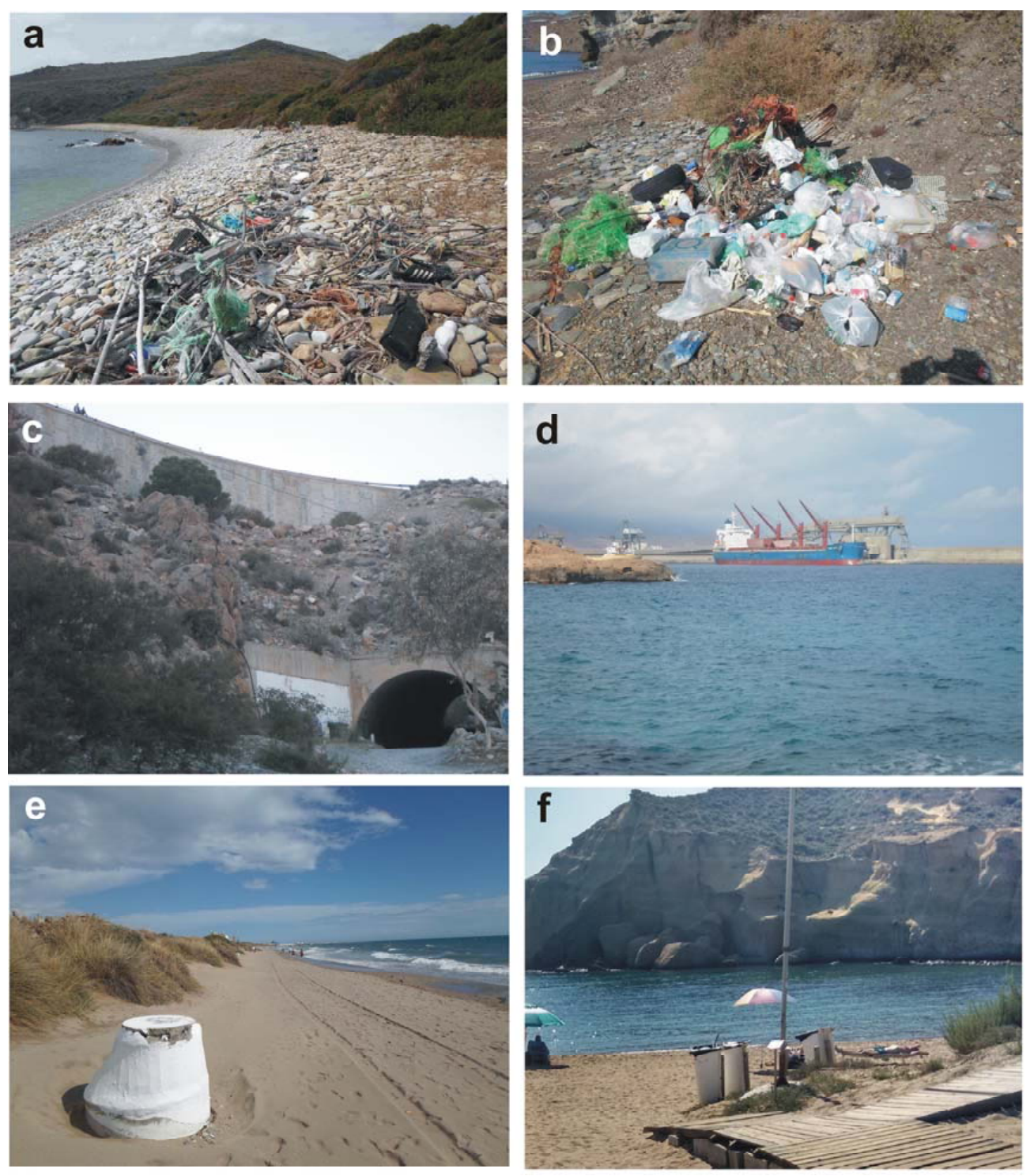

Figure 9. (a) Continuous accumulation of litter at Ensenada del Tolmo, Natural Park Estrecho de Gibraltar (Cadiz) and (b) single accumulations at El Ruso (Granada); (c) Tunnel for beach access of great scenic impact at La Rijana, SAC Acantilados y Fondos Marinos Calahonda (Granada); (d) Industrial port at Carboneras, close to Los Muertos, Natural Park Cabo de Gata-Nijar (Almeria). (e) sewerage infrastructures at Cabopino, Natural Monument Dunas de Artola (Malaga) and (f) utilities on the backbeach at Los Cocedores (Almeria). 
(c). Sewage discharge evidence, was virtually absent (Table 4).

(d). Non-built environments are usually natural or consists of cultivations (Caleta de Maro, El Ruso, Table 4).

(e). Built environment is "historic", natural and "very sensitively designed" (e.g., El Cambrón, Cala San Pedro, Cala del Plomo, etc., Table 4). Zonation and typology of human activities are strictly regulated in PORN and this preserves the conservational status, i.e., natural/historical heritage and environmental quality - central elements of protected areas attractiveness as tourist destinations [87].

(f). Access type is linked to the visual impact of car park areas. It is important to limit parking area dimensions and visual impacts, and this is regulated by both PORN and PRUG documents. As an example, at Maro-Cerro Gordo and Cabo de Gata-Nijar (Table 4), public transport has been established to reduce the number and associated impacts of cars and visitors. In fact, access type is a crucial parameter from a management point of view because it partially determines the number of visitors (Figure 9c). As previously observed, the determination of intensity of use and the regulation of access are key issues in protected areas management [88]. So, although tourism and visits to these areas brings a multitude of benefits to local communities and economies, an excessive number of visitors can have a devastating impact on the natural environment $[50,89]$.

(g). At Skyline high scores were usually observed because the absence of human constructions/settlements strictly regulated and mapped within PORN. Exceptions to the previous assumptions are sites located at the border of protected areas, such as Los Muertos (Almería, D: 0.93), located at the border of Cabo de Gata-Nijar Natural Park. In past years, an industrial port was built at Carboneras at a $1500 \mathrm{~m}$ distance from the park edge, creating a conflict between pre-existing natural environment and the associated ecotourism and other kind of activities, in this case, industrial shipping (Figure 9d). Because of port presence, the skyline parameter achieves a value of 1 (parameter 25, "very unattractive", Tables 2 and 4). The absence of the port would give a value of 4 at skyline and a final D: 1.18 .

(h). Utilities are not very common and their abundance and typology depends on the management strategies of each specific protected area and the PRUG directives to which is subjected. At Cabopino sewage structures are observed (Figure 9e), but, usually utilities are represented by litter bins and information panels. Appropriate litter bins distribution and maintenance is compulsory at any beach site for littering prevention and recycling [82]. Visitor information and provision of interpretation services are mandatory for protected area management, favouring resource protection, ensuring quality visitor experiences, and policy enlargement [50]. The model used at the Natural Park of Cabo de Gata-Nijar constitutes a good example, as it is able to appropriately maintain and manage $60 \mathrm{~km}$ of coast. Information panels and litter bins have low visual impact (Table 4). At Punta Boquerón (D: 0.98, Natural Park Bahia de Cadiz, Table 4), several utilities (litter bins, etc.) are observed because management policies are more permissive with respect to other protected areas. If visual impact of actual big yellow litter bins is dissimulated, the utilities score would be 4 and the D value 1.11. A similar situation is observed at Los Cocedores where utilities are represented by litter bins, a street lamp, and information panels that are directly placed on the back beach (Figure 9f). If their visual impact is reduced, the site will upgrade to Class I (D: 1.10).

In order to reduce human impact, which is related to the fact that visitors are essentially interested in the beach, local managers have to promote a diversification of activities under an ecotourism perspective linked to the great biodiversity, pristine nature, and rich cultural and historical heritage of the investigated sites. Ecotourism is the best way to conserve and raise awareness of protected areas, enhance sustainable development and education, and produce a positive effect on nearby communities $[72,90]$. Such objectives can be achieved by conserving and enhancing the natural environment by means of educational programs instead of tourism infrastructure developments [91], as well as by strengthening responsibility for the environment among all of the involved actors, e.g., stakeholders, operators, managers, and residents [92]. Any area that is classified as Class I or II means that it has a high scenic value, and this should be protected in any future development plans 
for that area. Hence, local managers have to prepare management plans that take into consideration government policies, the ecosystem, and the complex socio-economic interests of tourism stakeholders to create active ecotourism that is not merely attempting to minimize negative environmental impacts, but directly promoting environmental conservation. As an example, it is mandatory to identify recreation patterns along the coast and outline a zonation policy that ensures the non-destruction of sensitive ecological sites while easing visitor pressure in congested areas. This may possibly include sustainable transporting systems, as biker-friendly and pedestrian routes, supported by education and guiding information for tourists and visitors. As expected results, such as, environmental friendly tourist activities increase tourism profits and the associated enhancement of resident's incomes and founds for ecosystem restoration [93], and can be developed during several months per year in contrast with the traditional bathing activities very limited to summer period.

\section{Conclusions}

The $910 \mathrm{~km}$ long coast of Andalusia (SW Spain) constitutes a popular destination for many national and international visitors that are attracted by beach-related activities in urban sites and the great scenic beauty of rural and remote sites. Scenery is a very important factor for beach tourism and drives the economy of many coastal areas whose capacity for growth appears to be almost limitless. Scenic evaluation represents an extremely relevant tool for coastal preservation/conservation and development, as this provides a sound scientific basis for any envisaged management plan to preserve existing pristine areas or promote new ones, i.e., the establishment of Coastal Heritage Sites, i.e., a designation based on the scenic value of the site, and to limit the continuous and unsustainable coastal development model that is essentially related to the $3 S$ market, exclusively based on financial criteria.

This paper presents the coastal scenery assessment at 50 sites along the Andalusia coast obtained, according to a methodology that is based on fuzzy logic analysis and parameter weighting matrices to overcome subjectivity and quantify uncertainties. The method allows locations to be classified into five classes, from Class I, attractive natural sites, to Class V, urbanised areas with a poor scenic value, but this paper is only concerned with the first two classes. Eighty-eight percent of the investigated sites are located in protected areas, which cover 35\% of the Andalusia coastline. Most of sites are located within the Natural Park Cabo de Gata-Nijar (24\%), the Natural Park of Gibraltar Strait (18\%), and the Natural Place Acantilado de Maro-Cerro Gordo (12\%) and the Natural and National parks of Doñana ( $8 \%)$. Almeria and Cadiz are the provinces with the most abundant number of investigated sites, followed by Malaga and Granada, along which coasts-deeply urbanised since the $70 \mathrm{~s}$, only eleven sites were recorded.

Dealing with the scenic characteristics, 41 sites were included in Class I and 9 sites in Class II. Class I sites showed huge scenic values at cliff, rock shore, valley, skyline landform, special features, etc. that are often related to the presence of the Betic Chain or an undulating Tertiary volcanic relief at Cabo de Gata. Class II sites are characterized by attractive natural areas with high landscape values, but slightly lower scoring of natural scenic parameters because of the absence of mountainous landforms and/or special landscape features. Lower scores of human parameters are also recorded and related to the increase of human activities/impacts often linked to their location at the edges of protected areas. The skyline is often not pristine and nearby human settlements, harbours, intensive cultivations, etc. are visible, as is the presence of litter and utilities. This is often linked to the existence (and often coexistence) of two models of management at Andalusia protected areas:

(i) the intensive model, i.e., facilities provided are designed to give the minimum effect on the beauty of the protected area but facilitate maximum public enjoyment; and,

(ii) remote, which retains areas in a relatively inaccessible and untouched state.

As a result, dissimilar management strategies are applied at areas with different forms of protection and often at areas with the same protection status. An example, concerning noise disturbance, strictly related to carrying capacity and appropriate management is observed at 
Maro-Cerro Gordo protected area, which implemented a limited access policy. As regards litter, accumulations are linked to items stranded on the beach by waves and currents as well as to the absence of periodic cleaning operations. As an example, the establishment of cleaning operations at Ensenada del Tolmo (Class II) would upgrade the site to Class I. At many places, utilities are linked to the presence of litter bins and information panels. At Punta Boquerón (Natural Park Bahia de Cadiz), striking yellow litter bins are observed because management policies are more permissive with respect to other protected areas. From a scenic point of view, it is mandatory to reduce their visual impact: the model that is used at the Natural Park of Cabo de Gata-Nijar is a good example since information panels and litter bins have a low visual impact. Finally, since many visitors are essentially interested in beach attractions, it should be mandatory to promote a diversification of activities under an ecotourism perspective that is linked to the great biodiversity, pristine nature, and rich cultural and historical heritage of the investigated sites.

Author Contributions: Alexis Mooser and Giorgio Anfuso designed the study and participated in all phases. Allan T. Williams also participated in the development of the study and provided a structural discussion. Carlos Mestanza and Alexis Mooser carried out the literature review and analyzed the results. All of the authors participated in the field work and made contributions to this paper.

Funding: This research received no external funding.

Acknowledgments: This work is a contribution to the Andalusia Research Group RNM-328 (University of Cádiz, Spain).

Conflicts of Interest: The authors declare no conflict of interest.

\section{References}

1. Doxey, G. A Causation Theory of Visitor-Resident Irritants: Methodology and Research Inferences. The Impact of Tourism. In The Sixth Annual Conference Proceedings; The Travel Research Association: San Diego, CA, USA, 1975; pp. 195-198.

2. Butler, R.W. The concept of the tourist area life-cycle of evolution: Implications for management of resources. Can. Geogr. 1980, 24, 5-12. [CrossRef]

3. Pratt, S. Economic linkages and impacts across the TALC. Ann. Tour. Res. 2011, 38, 630-650. [CrossRef]

4. Lagiewski, R. The Application of the Talc model: A literature survey. In Aspects of Tourism: The Tourism Area Life Cycle, Vol.1 Applications and Modifications; Butler, R., Ed.; Cromwell Press: Great Britain, UK, 2006; pp. 27-50.

5. Leiper, N. Tourism Management; Arnold: London, UK, 2004.

6. Leiper, N. Tourist Attraction Systems. A Model of Tourism Attractions. 1990. Available online: https: / / www.youtube.com/watch?v=ZLYtGCEDkDw (accessed on 6 April 2018).

7. Klein, Y.L.; Osleeb, J.P.; Viola, M.R. Tourism generated earnings in the coastal zone: A regional analysis. J. Coast. Res. 2004, 20, 1080-1088. [CrossRef]

8. United Nations World Tourism Organization (UNWTO). Tourism Highlights Edition; UNWTO: Madrid, Spain, 2017; p. 16.

9. Hannan, K.; Knox, D. Understanding Tourism. A Critical Introduction; SAGE: London, UK, 2010.

10. Becker, E. Overbooked: The Exploding Business of Travel and Tourism; Simon \& Schuster: New York, NY, USA, 2013; p. 448.

11. Benoit, G.; Comeau, A. A Sustainable Future for the Mediterranean: The Blue Plan's Environment and Development Outlook; Earthscan: London, UK, 2005; p. 428.

12. Dodds, R.; Kelman, I. How climate change is considered in sustainable tourism policies: A case of the Mediterranean islands of Malta and Mallorca. Tour. Rev. Int. 2008, 12, 57-70. [CrossRef]

13. Ministerio de Energía, Turismo y Agenda Digital (MINETAD). Nota de Prensa: Balance del Sector Turístico 2016; MINETAD: Madrid, Spain, 2017.

14. Instituto Nacional de Estadísticas (INE). Nota de Prensa: Encuesta de Turismo de Residentes (ETR/FAMILITUR). Cuarto Trimestre de 2016 y año 2016; INE: Mexico City, Mexico, 2017.

15. Consejería de Turismo y Deporte (CTD). Balance del Año Turístico 2016 en Andalucía; CTD: Sevilla, Spain, 2017. 
16. Arenas, P. Gestión del litoral y política pública en España [Coastal Management and public policy in Spain]. In Manejo Costero Integrado y Política Pública en Iberoamérica: Un Diagnóstico; Barragán Muñoz, J.M., Ed.; Necesidad de cambio Red IBERMAR (CYTED): Cádiz, Spain, 2009; pp. 353-380.

17. Clark, J.R. Coastal Zone Management Handbook; CRC Press/Lewis Publishers: Boca Raton, FL, USA, 1996; p. 720.

18. Houston, J.R. The economic value of beaches-A 2013 update. Shore Beach 2013, 81, 3-11.

19. Wilson, M.; Liu, S. Non-market values of ecosystem services provided by coastal and nearshore and marine systems. In Ecological Economics of the Oceans and Coasts; Patterson, M., Glavovicic, B., Eds.; Edward Elgar: Cheltenham, UK, 2008; p. 384.

20. Ergin, A.; Karaesmen, E.; Micallef, A.; Williams, A.T. A new methodology for evaluating coastal scenery: Fuzzy logic systems. Area 2004, 36, 367-386. [CrossRef]

21. Williams, A.T. Definitions and typologies of coastal tourism beach destinations. In Disappearing Destinations: Climate Change and Future Challenges for Coastal Tourism; Jones, A., Phillips, M., Eds.; CABI: Wallingford, UK, 2011; p. 296.

22. Williams, A.T.; Micallef, A. Beach Management: Principles and Practices; Earthscan: London, UK, 2009 ; p. 480.

23. Aguilo, E.; Alegre, J.; Sard, M. The persistence of the sun and sand tourism model. Tour. Manag. 2005, 26, 219-231. [CrossRef]

24. Linton, D.L. The assessment of scenery as a natural resource. Scott. Geogr. Mag. 1968, 84, 219-238. [CrossRef]

25. Clark, B.D.; Gilad, A.; Bisset, R.; Tomlinson, P. Perspectives in Environmental Impact Assessment; Springer: Amsterdam, The Netherlands, 1984.

26. Poon, A. Tourism, Technology and Competitive Strategies; CAB International: Wallingford, UK, 1993.

27. Ergin, A.; Williams, A.T.; Micallef, A. Coastal scenery: Appreciation and evaluation. J. Coast. Res. 2006, 22, 958-964. [CrossRef]

28. Anfuso, G.; Williams, A.T.; Casas Martínez, G.; Botero, C.M.; Cabrera Hernández, J.A.; Pranzini, E. Evaluation of the scenic value of 100 beaches in Cuba: Implications for coastal tourism management. Ocean Coast. Manag. 2017, 142, 173-185. [CrossRef]

29. Langley, R.A. Coastal Scenic Assessment of the North Canterbury Coast, New Zealand. Unpublished. Master's Thesis, Univercity of Canterbury, Christchurch, New Zealand, 2006; p. 65.

30. Ullah, Z.; Johnson, D.; Micallef, A.; Williams, A.T. From the Mediterranean to Pakistan and back-Coastal scenic assessment for tourism development in Pakistan. J. Coast. Conserv. Manag. 2010, 14, 285-293. [CrossRef]

31. Williams, A.T.; Micallef, A.; Anfuso, G.; Gallego Fernández, J.B. Andalusia, Spain: An assessment of coastal scenery. Landsc. Res. 2012, 373, 327-349. [CrossRef]

32. Anfuso, G.; Williams, A.T.; Cabrera Hernández, J.A.; Pranzini, E. Coastal scenic assessment and tourism management in western Cuba. Tour. Manag. 2014, 42, 307-320. [CrossRef]

33. Williams, A.T.; Sellers, V.; Philips, M.R. An Assessment of UK Heritage Coasts in South Wales: J A Steers revisited. In Proceedings of the 9th International Coastal Symposium, Sunshine Coast, Australia, 20-24 August 2007; pp. 453-458.

34. Chambers. Chambers Dictionary; Chambers: Edinburg UK, 2000.

35. Williams, A.T. The Concept of Scenic Beauty in a Landscape. In Coastal Scenery; Rangel-Buitrago, N., Ed.; Springer: Berlin, Germany, 2018.

36. Leopold, L.B. Quantitative Comparisons of Some Aesthetics Factors Among Rivers; US Geological Survey: Washington, DC, USA, 1969.

37. Penning Rowsell, E.C. A public preference evaluation of landscape quality. Reg. Stud. 1982, 16, 97-112. [CrossRef]

38. Kaplan, R.; Kaplan, S. The visual environment: Public participation in design and planning. Soc. Issues 1989, 45, 59-86. [CrossRef]

39. Countryside Council for Wales (CCW). Annual Report, The Welsh Landscape: Our Inheritance and its Future Protection and Enhancement; CCW: Bangor, Wales, 1996.

40. Countryside Council for Wales (CCW). The LANDMAP Information System, 1st ed.; CCW: Bangor, Wales, 2001.

41. Macaulay. Review of Existing Methods of Landscape Assessment. 2014. Available online: www.macaulay.ac. uk/ccw/task-two/evaluate.html (accessed on 4 August 2016). 
42. Dupont, L.; Antrop, M.; Van Eetvelde, V. Does landscape related expertise influence the visual perception of landscape photographs? Implications for participatory landscape planning and management. Landsc. Urban Plan. 2015, 141, 68-77. [CrossRef]

43. Williams, A.T.; Lavalle, C.D. Coastal Landscape Evaluation and Photography. J. Coast. Res. 1990, 6, 1011-1020.

44. Millennium Ecosystem Assessment (MEA). Ecosystems and Human Well-Being: Synthesis; Island Press: Washington, DC, USA, 2005; p. 155.

45. Chica Ruiz, J.A.; Pérez Cayeiro, M.L.; Barragán, J.M. La Evaluación de los ecosistemas del milenio en el litoral español y andaluz. Ambienta 2012, 98, 94-104.

46. Barragán Muñoz, J.M. Politica, Gestión y Litoral, una Nueva Visión de la Gestión Integrada de Áreas Litorales; Tebar Flores: Madrid, Spain, 2014; p. 688.

47. Plan del Turismo Español Horizonte 2020. Ministerio de Industria, Turismo y Comercio. 2007. Available online: http:/ / www.tourspain.es/eses/VDE/Documentos\%20Vision\%20Destino\%20Espaa/Plan_ Turismo_Espa\%C3\%B1ol_Horizonte_2020.pdf (accessed on 6 February 2018).

48. Priskin, J. Assessment of natural resources for nature-based tourism: The case of the Central Coast Region of Western Australia. Tour. Manag. 2001, 22, 637-648. [CrossRef]

49. Pedersen, A. Managing Tourism at World Heritage Sites: A Practical Manual for World Heritage Site Managers; UNESCO World Heritage Centre: Paris, France, 2002; p. 96.

50. Leung, Y.F.; Spenceley, A.; Hvenegaard, G.; Buckley, R. Tourism and Visitor Management in Protected Areas: Guidelines towards Sustainability. In Best Practice Protected Area Guideline; IUCN: Gland, Switzerland, 2015.

51. Manno, G.; Anfuso, G.; Messina, E.; Williams, A.T.; Suffo, M.; Liguori, V. Decadal evolution of coastline armouring along the Mediterranean Andalusia littoral (South of Spain). Ocean Coast. Manag. 2016, 124, 84-99. [CrossRef]

52. Anfuso, G.; Rangel Buitrago, N.; Cortés Useche, C.; Iglesias Castillo, B.; Gracia, F.J. Characterization of storm events along the Gulf of Cadiz (eastern central Atlantic Ocean). Int. J. Climatol. 2016, 36, 3690-3707. [CrossRef]

53. Red de Espacios Naturales Protegidos de Andalucía (RENPA). Informe Actualizado de la Superficie RENPA (Mapa). Available online: http://www.juntadeandalucia.es/medioambiente/portal_web/web/temas_ ambientales/espacios_protegidos/01_renpa/05_areas_protegidas/mapa_cartografia_renpa/2017_mapa_ renpa.jpg (accessed on 6 February 2018).

54. Chica Ruiz, J.A.; Barragan, J.M. Estado y Tendencia de los Servicios de los Ecosistemas Litorales de Andalucía; Consejería de Medio Ambiente: Sevilla, Spain, 2011; p. 112.

55. Plan de Protección del Corredor Litoral de Andalucía (PPCA). Informe de Sostenibilidad de la Consejería de Agricultura; Pesca y Medio Ambiente: Sevilla, Spain, 2013.

56. Red de Información Ambiental de Andalucía (REDIAM). WBS (Web Map Services) Correspondiente a la Delimitación de la RENPA. Available online: http:/ / www.juntadeandalucia.es/medioambiente/site/rediam (accessed on 6 February 2018).

57. RENPA. Listado de las Áreas Protegidas Presentes en Andalucía. Available online: http://www. juntadeandalucia.es/medioambiente/site/portalweb/menuitem (accessed on 6 February 2018).

58. Kaye, R.; Alder, J. Coastal Planning and Management; E \& FN Spon: London, UK, 1999; p. 375.

59. Steers, J.A. Coastal preservation and planning. Geog. J. 1944, 104, 7-27. [CrossRef]

60. Teale, E.W. Wandering through Winter; Dodd, Mead and Co.: New York, NY, USA, 1965.

61. British Council Report (BCR). Coastal Scenic Assessments at Selected Sites in Turkey, UK and Malta; Final Report; British Council Office: Ankara, Turkey; Valetta, Malta, 2003; p. 64.

62. Eletheriadis, N.; Tsalikidis, I.; Manos, B. Coastal landscape preference evaluation. A comparison among tourists in Greece. Environ. Manag. 1990, 14, 475-487. [CrossRef]

63. Dr Beach. Available online: www.drbeach.org/online/dr-beachs-50-criteria/ (accessed on 4 April 2018).

64. Pranzini, E.; Anfuso, G.; Botero, C.; Cabrera, A.; Apin Campos, Y.; Casas Martinez, G.; Williams, A.T. Beach colour at Cuba and management issues. Ocean Coast. Manag. 2016, 126, 51-60. [CrossRef]

65. Patel, A. Analytical structures and analysis of fuzzy PD controllers with multifuzzy sets having variable cross-point level. Fuzzy Sets Syst. 2002, 129, 311-334. [CrossRef]

66. Zadeh, L. Fuzzy Sets. Inf. Control 1965, 8, 338-353. [CrossRef]

67. Rangel-Buitrago, N.; Anfuso, G.; Correa, I.; Ergin, A.; Williams, A.T. Assessing and managing scenery of the Caribbean coast of Colombia. Tour. Manag. 2013, 35, 41-58. [CrossRef] 
68. Iglesias, B.; Anfuso, G.; Uterga, A.; Arenas, P.; Williams, A.T. Scenic value of the Basque Country and Catalonia coasts (Spain): Impacts of tourist occupation. J. Coast. Conserv. 2018, 22, 247-261. [CrossRef]

69. Young, R.; Stancheva, M.; Stanchev, H.; Palazov, A. Global lessons or future development along the Black sea coast of Bulgaria. In Proceedings of the Geological Society of America Annual Meeting, Denver, CO, USA, 27-30 October 2013.

70. United Nations Environment Programme (UNEP). Marine Litter, an analytical overview. In UNEP Report; UNEP: Nairobi, Kenya, 2005; p. 58.

71. Williams, A.T. Coastal conservation policy development in England and Whales with special reference to the Heritage Coast concept. J. Coast. Res. 1987, 3, 99-106.

72. Stancheva, M.; Stanchev, H.; Peev, P.; Anfuso, G.; Willliams, A.T. Coastal protected areas and historical sites in North Bulgaria-Challenges, mismanagement and future perspectives. Ocean Coast. Manag. 2016, 130, 340-354. [CrossRef]

73. Botero, C.; Williams, A.T.; Cabrera, J.A. Advances in beach management in Latin America: An overview from certification schemes. In Environmental Management Governance: Advances in Coastal and Marine Resources, Coastal Research Library; Finkl, C.W., Makowski, C., Eds.; Springer: Berlin, Germany, 2015; p. 472.

74. Ariza, E.; Jiménez, A.J.; Sardá, R. Seasonal evolution of beach waste and litter during the bathing season on the Catalan coast. Waste Manag. 2008, 28, 2604-2613. [CrossRef] [PubMed]

75. Gabrielides, G.; Golik, A.; Loizides, L.; Marino, M.; Bingel, F.; Torregrossa, M. Manmade garbage pollution on the Mediterranean coastline. Mar. Pollut. Bull. 1991, 23, 437-441. [CrossRef]

76. Galgani, F.; Leaute, J.P.; Moguedet, P.; Souplet, A.; Verin, Y.; Carpenter, A.; Goraguer, H.; Latrouite, D.; Andral, B.; Cadiou, Y.; et al. Litter on the sea floor along European coasts. Mar. Pollut. Bull. 2000, 40, 516-527. [CrossRef]

77. Maziane, F.; Nachite, D.; Anfuso, G. Artificial polymer materials debris characteristics along the Moroccan Mediterranean coast. Mar. Pollut. Bull. 2018, 128, 1-7. [CrossRef] [PubMed]

78. Topçu, E.N.; Öztürk, B. Abundance and composition of solid waste materials on the western part of the Turkish Black Sea seabed. Aquat. Ecosyst. Health Manag. 2010, 13, 301-306. [CrossRef]

79. Stefatos, A.; Charalampakis, M.; Papatheodorou, G.; Ferentinos, G. Marine debris on the seafloor of the Mediterranean Sea: Examples from two enclosed gulfs in western Greece. Mar. Pollut. Bull. 1999, 38, 389-393. [CrossRef]

80. Aliani, S.; Griffa, A.; Molcard, A. Floating debris in the Ligurian Sea, northwestern Mediterranean. Mar. Pollut. Bull. 2003, 46, 1142-1149. [CrossRef]

81. Poeta, G.; Conti, L.; Malavasi, M.; Battisti, C.; Acosta, A.T.R. Beach litter occurrence in sandy littorals: The potential role of urban areas, rivers and beach users in central Italy. Estuar. Coast. Shelf Sci. 2016, 181, 231-237. [CrossRef]

82. Williams, A.T.; Randerson, P.; Di Giacomo, C.; Anfuso, G.; Macias, A.; Perales, J.A. Distribution of beach litter along the coastline of Cádiz, Spain. Mar. Pollut. Bull. 2016, 107, 77-87. [CrossRef] [PubMed]

83. Coe, J.M.; Rogers, D.B. Marine Debris: Sources, Impacts and Solutions; Springer: New York, NY, USA, 1997; p. 432.

84. UNEP. Plastic Debris in the Ocean Emerging Issues in Our Global Environment. University of Surrey, 1987 The Public Health Implications of Sewage Pollution of Bathing Water Guildford: The Robens Institute of Industrial and Environmental Safety; UNEP: Nairobi, Kenya, 2011; p. 53.

85. Anfuso, G.; Lynch, K.; Williams, A.T.; Perales, J.A.; Pereira da Silva, C.; Nogueira Mendes, R.; Maanan, M.; Pretti, C.; Pranzini, E.; Winter, C.; et al. Comments on Marine Litter in Oceans, Seas and Beaches: Characteristics and Impacts. Ann. Mar. Biol. Res. 2015, 2, 1008-1012.

86. Krelling, A.; Williams, A.T.; Turra, A. Differences in perception and reaction of tourist groups to beach marine debris that can influence a loss of tourism revenue in coastal areas. Mar. Policy 2017, 85, 87-99. [CrossRef]

87. Fonseca, C.; Pereira da Silva, C.; Calado, H.; Moniz, F.; Bragagnolo, C.; Gil, A.; Phillips, M.; Pereira, M.; Moreira, M. Coastal and marine protected areas as key elements for tourism in small islands. J. Coast Res. 2014, 70, 461-466. [CrossRef]

88. Williams, A.T. Management strategies for coastal conservation in South Wales, U.K. In Recreational Uses of Coastal Areas; Fabbri, P., Ed.; Kluwer Academic Publishers: Norwell, MA, USA, 1990; p. 285.

89. Das, M.; Chatterjee, B. Ecotourism: A panacea or a predicament? Tour. Manag. Perspect. 2015, 14, 3-16. [CrossRef] 
90. Snyman, S. High-end Ecotourism and Rural Communities in Southern Africa: A Socio-Economic Analysis. Ph.D. Thesis, University of Cape Town, Cape Town, South Africa, 2013.

91. Choi, Y.E.; Doh, M.; Park, S.; Chon, J. Transformation Planning of Ecotourism Systems to Invigorate Responsible Tourism. Sustainability 2017, 9, 2248. [CrossRef]

92. Stem, C.J.; Lassoie, J.P.; Lee, D.R.; Deshler, D.D.; Schelhas, J.W. Community participation in ecotourism benefits: The link to conservation practices and perspectives. Soc. Nat. Resour. 2003, 16, 387-413. [CrossRef]

93. Timothy, D. Destination communities and responsible tourism. In Responsible Tourism: Concepts, Theory and Practice; Leslie, D., Ed.; CABI: Oxfordshire, UK, 2012; p. 77.

(C) 2018 by the authors. Licensee MDPI, Basel, Switzerland. This article is an open access article distributed under the terms and conditions of the Creative Commons Attribution (CC BY) license (http:/ / creativecommons.org/licenses/by/4.0/). 